SANDIA REPORT

SAND96-2459 * UC-005

Unlimited Release

Printed October 1996

$$
\begin{aligned}
& \text { i.t? }
\end{aligned}
$$

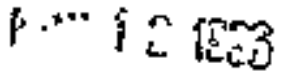

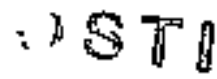

\title{
Aspen: A Microsimulation Model of the Economy
}

\author{
N. Basu, R. J. Pryor, T. Quint, T. Amold
}

\section{Piepared by}

Sentia Kaliong Loboratones

Aburquerqus, New Mexloo 67185 and Lwermore, Calloma 84550 for the United Stales Deperiment of Energy

under Coniract DEACO494AL85000

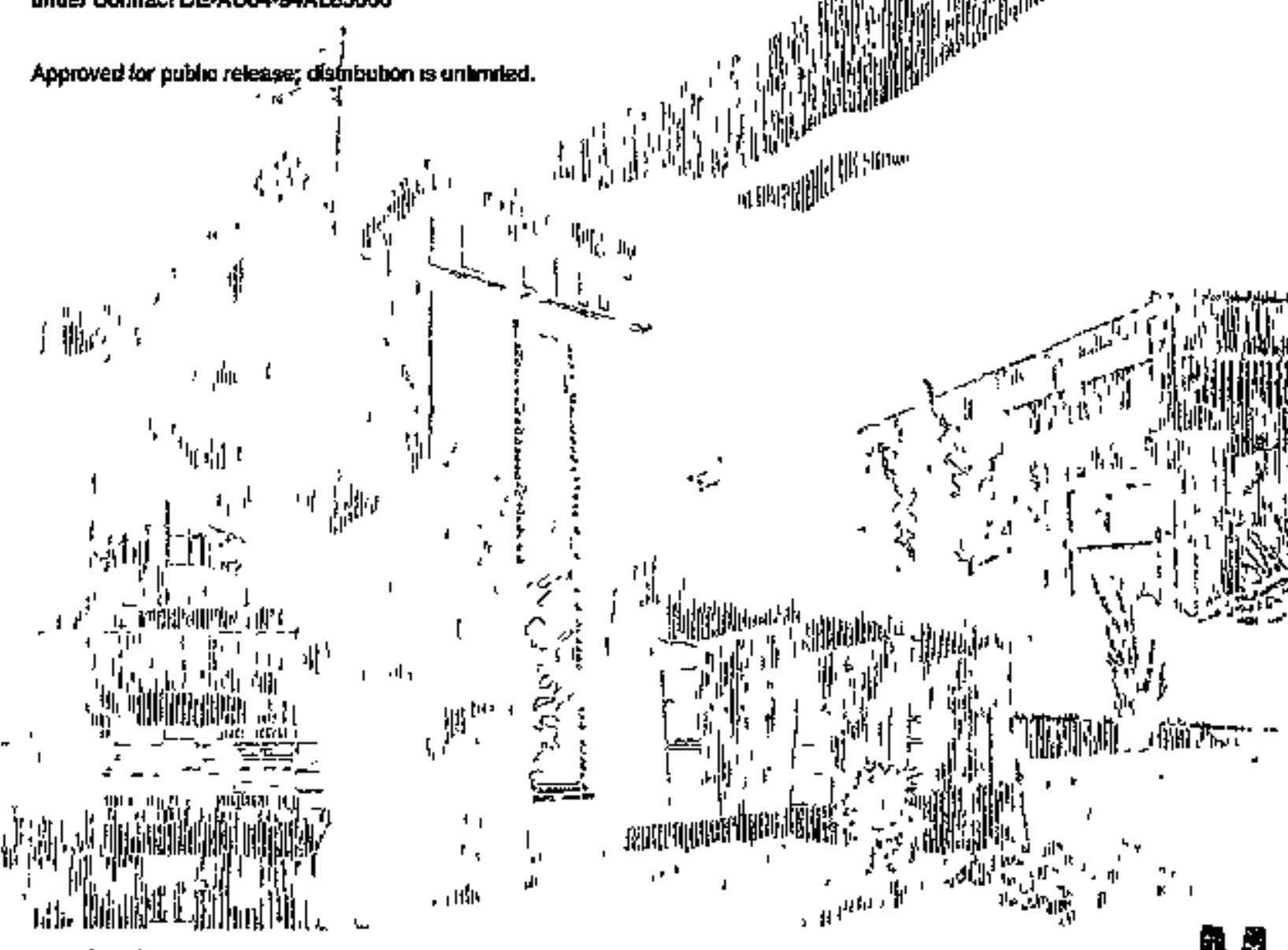


Issued by Sandla National Intoratories, operated for the United States Department of Energy by Sandia Corptration.

NOTICE: This report was prepared as an account of work gponsored by an agency of the United States Government. Neither the United States Governmetat nor any agency thereet, nor any of their exployees, nor any of their contractors, subcontractors, or their employees, makes any wazranty, express or implied, or assumes any legal lability or responsibility for the accuracy, completeness, or usefulness of any information, apparatus, product, or process diselpsed, or repregents that its use wonld not infringe privately owned rights. Reforenos berein to eny specific commercial praduct, process, or service by trade name, trademark, manufacturer, or otherwise, does not necessarily constitute or imply its endarsement, recommendation, or favoring by the United States Government, any agency thereof or any of their contractors or snbcontractors. The views and opinions expressed herein do not necessarily state or refect thoge of the United States Government, any agency there of or any of their contractors.

Printed in the United Skates of Amorica This report has been reproduced directily from the best available copy.

Aratiable to DOE and DOE cantractors from

Office of Stientific and Technical Information

PO Box 62

Oek Ridge, TN 37881

Prices available from (615) 576-9401, FTS 626-8401

Arailable to the public from

National Technical Information Service

US Department of Commerce

5285 Port Royal Rd

Springfield, VA22161

NTIS price cades

Printed copy: AD4

Microfiche topy: AOI 


\section{DISCLAIMER}

This report was preparted as an account of wak sponsored by an agtency of the Unfted States Government Neizhos the United States Gowernmost poe any agency thereof, nor any of theit exployes, antakes any warranty, express or inptiect, of assumes any legal biability of responsibitty for the accurasy, completeness, of uste fuliness of any information, apparatus, product, af process disclosed, of represents that its use woold nod infringe privately ownod rishts. Refierence herein to any spe. ctile commercial product, peocess, or service by trads nerre, trademark, manufacturef, or otherwise does not necescarily coestitute or impty its endoesement, reconmendation, or favocing by the United States Government of any agency theted. The views and opinions of suthors expressed herein do not necessarity state or reflect those of the Uaited States Gowermment or any agency thereof. 


\section{DISCLAIMER}

Portions of this document may be illegible in electronic image products. Images are produced from the best available original document. 
SAND96-2459

Distribution

Unilimited Release

Category UC-905

Printed October 1996

\title{
ASPEN: A MICROSIMULATION MODEL OF THE ECONOMY
}

\author{
N. Basu, R. J. Pryor, T. Quint, T. Amold \\ Program Management Department \\ Sandia National Laboratories \\ Albuquerçue, NM 87185
}

\begin{abstract}
This report presents Aspen. Sandia National Latoratories is developing this new agentbased microeconomic simulation model of the U.S. economy. The model is notable because it allows a large number of individual economic agents to be modeled at a high level of detail and with a great degree of freedom. Some features of Aspen are (a) a sophisticated message-passing system that allows mdividual pairs of agents to communicate, (b) the use of genetic algorithims to simulate the leaning of certain agents, and (c) a detailed financial sector that includes a banking system and a bond market. Results from nuns of the model are also presented.
\end{abstract}


Intentionally Left Blank

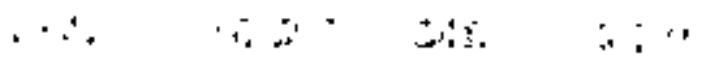




\section{Contents}

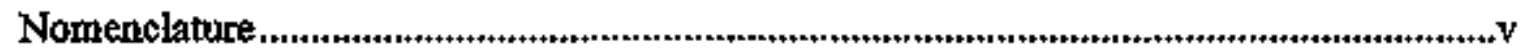

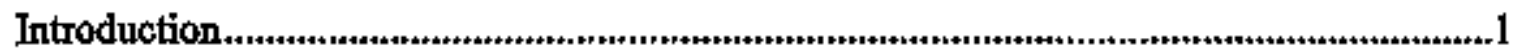

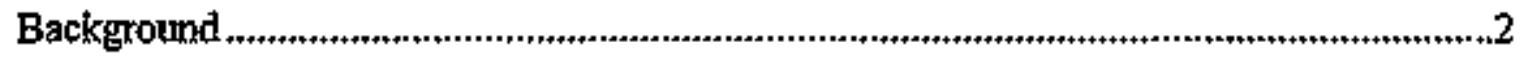

Aspen: The Model.........................................................................................................3

The Mechanics of the Model .................................................................................................. 3

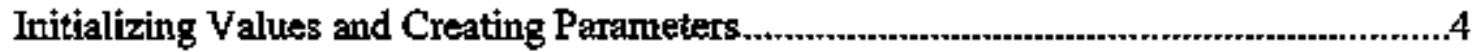

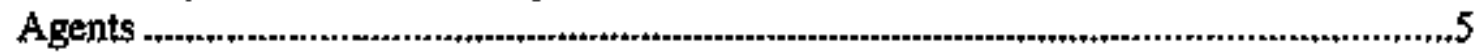

Results and Discussion ...................................................................................... 12

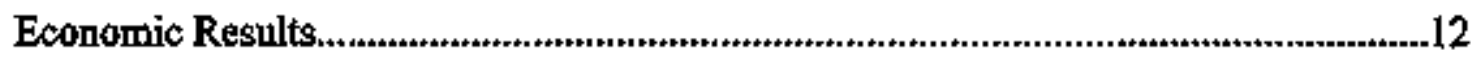

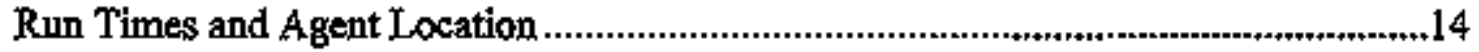

GALCS: Further Discussion ..................................................................................15

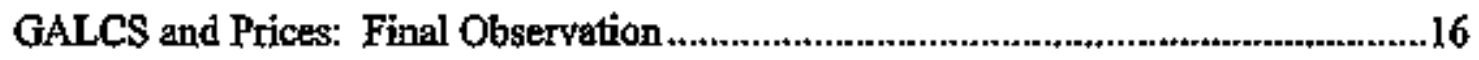

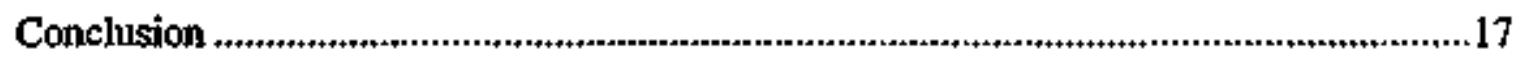

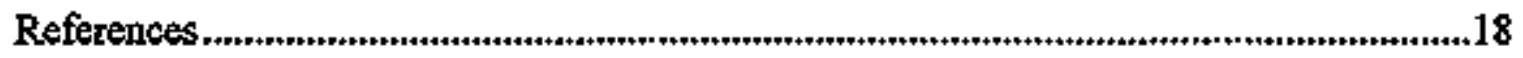

APPENDDX A Initializing Values and Creating Parameters ........................................ A-1

APPENDDX B Gtaphs Illustrating Study Results ........................................................

APPENDIX C Run Time Results ............................................................................ 
Intentionally Lêt Blank 


\section{Nomenclature}

Aspen

(an agent-based simulation model of the U.S. economy)

CGE

computable generai equilibrium

GALCS

genetic algorithm learring classifier system

GNP

gross national product

Sandja

Sandia National Laboratorites 
Intentionally Left Blank 


\title{
ASPEN: A MICROSIMULATION MODEL . OF THE ECONOMY
}

\author{
Introduction
}

This paper describes Aspen, a new sirnutation model of the U.S. economy that Sandia National Laborateries (Sandia) is developing. ${ }^{1}$ Aspen runs on Sandia's massively parallel Intel Paragon computer and is an agent-based Monte-Carlo simulation. Individual agents in the model represent real-life economic decision-makers. Aggregates of the agents' microeconomic actions generate macroeconomic quantities of interest.

The building blocks of Aspen are agents, the first of which is the household agent. The household agent works or collects unemployment or social security for income. This agent spends income on four consumer items, contributes to a savings account, or invests in bonds.

Fim agents produce four types of goods. The four types of firm agents are attomobile manufacturers, housing developers, producers of nondurable goods (such as food), and producers of nondurable goods the consumption of which is income dependent. Each firm uses capital equipment in addition to labor to produce goods. Each firm sets prices by using a genetic algorithm learning classifier system (GALCS). GALCS simulates firm-agent learning as the agent develops a pricing strategy.

The single government agent collects income, sales, and payroll tax. Also, this agent runs a social security system, pays tmemployment benefits, runs a public sector, and issues govermment bonds daring a deficit.

Finally, a well developed financial sector includes (a) banks that maintain household savings accounts, make consumer and business loans, and invest in bonds; (b) the federal reserve, which may conduct an expansionary or contractionary monetary policy; and (c) a financial market agent that reconciles demand and supply for bonds among the governinent, banks, and households.

The model omits certain important factors of the U.S. economy. For example, the defense industry, service sector, and stock markets are not represented. These elements are planned for a future version of the model. However, when we, the authors, tested the outcome of various federal monetary policies in the model (see Results and Discussion), the results agreed qualitatively with predictions based on economic theory and practice.

\footnotetext{
The model described here is an update of the prototype model described in Pryor-Basu-Quint (1996). In that paper, this paper's model is referred to as the developunental model.
} 
the results agreed qualitatively with predictions based on economic theory and practice. This result is significant for such a novel simulation technique (especially for use of the genetic algorithms). Hence, even in its current state, the model has merit.

This paper is organized in three major sections plus a conclusion. The Background section addresses microeconomic simulation. Aspen: The Model covers model mechanics, initializing and creating parameters, and agent descriptions. Results and Discussion presents economic results, run times, agent location, and GALCS and their relationship to price.

\section{Background}

Microsimulation of the economy refers to a model that simulates the actions of economic decision-makers individually and then generates macroeconomic quantities of interest by integrating those actions. Microsinulation is a relatively new approach; we know of only two such models of the U.S. economy. ${ }^{2}$ Potentially, Aspen affords several advantages over traditional techniques (macroeconometric or computable general equilibrium [CGE]) of modeling the economy:

(a) The procedure does not require a functional form for its endogenous relationships (as macroeconometric and CGE models do). The user has great freedom when modeling individual agent behavior and can model in detail. For example, Aspen simulates the leaming of some agents by using genetic algorithm learning classifier systems (GALCS) (see Aspen: The Model). In addition, the effect of certain nonlinear legal, regulatory, and/or policy changes (such as in tax law) can be modeled explicitly.

(b) The procedure is individual-agent-based. Therefore, the user must build microeconomic models of the individual decision-maker rather than macroeconomic models of markets. Existing rich sources of micro-level data are available.

(c) The user can easily model a stochastic element using a simple random number generator.

Until now using microeconomic simulation had two major disadvantages: First, because the technique is so new, minor modeling problems had not been solved, and model parameter values had not been estimated. Hence, at present this type of model cannot forecast as accurately as a macroeconometric or a CGE model can. Second, tracking

${ }^{2}$ One is the Urban Institute Model developed by Guy Orcute See Orcutt-Caldwell-Wertheimer 1976. The other is Robert Bennett and Battara Berogriann's Transaction Moded (Beniett-Bergmann, 1986). 
numerous agents-especially if they are modeled in great detail-can require an enormous computing capacity. However, given time and computing facilities such as Sandia's Intel Paragon (currently the nation's fastest computer), microeconomic simulation models should eventually match their classical counterparts in capability and forecasting accuracy.

\section{Aspen: The Model}

This section discusses model mechanics, initializing and creating parameters, and the Aspen agents (including households, firms, banks, government, the financial market, the federal reserve, and the realtor and capital-goods producer).

\section{The Mechanics of the Model}

In Aspen, decision-makers in the economy are called agents. There are many classes (types) of agents, which are organized into two groups. The first group includes those classes for which there will be many agents representing them in a calculation. These classes are households, banks, and four types of fims: food producers, other nondurablegoods producers, automobile makers, and housing developers. The second group of classes will have only a single agent representing them in a calculation. These classes are government, federal reserve, capital goods producer, and a financial market agent.

Each agent behaves the way a real counterpart of the same type would. Microsimulation traces the agent's daily actions (buying food, hiring workers, selling bonds, collecting welfare payments, conducting open market operations, etc.). Agents in the same class draw from the same decision rules. For example, if a renter household agent decides to buy a home, the agent must apply for a 30-year loan. Payments will be at most $35 \%$ of the agent's income. ${ }^{3}$ However, other renter agents may take different actions because (a) they may be in different states (that is, two household agents at a particular time may have different incomes and, therefore, opt for different sized loans); or (b) they may draw different random numbers and decide not to buy a home at all.

The model uses a system of message passing that allows agents to perform actions. Time sequencing is key to message passing. In Aspen, time is divided into discrete periods or days. Every day is divided into 11 stages. An agent is processed once per stage. This

${ }^{3}$ The parameters 30 (year) and $35 \%$ can be changed at the discretion of the user during the microsimularion nun. See Initializing Values and Creating Paramezers. 
means the agent (a) reads any incoming messeges and acts upon them, then (b) takes allowable independent actions according to that agent's cturent status.

Most actions are allowed once at most per day during a specified stage. For instance, an automaker agent pays income tax only during stage l each day. To accomplish this, the automaker debits an account by the requisite amount and sends a message to the government saying "I'm paying taxes of $\$ \mathrm{x}$ " During processing, the government agent. reads the incoming message and credits the automaker's tax payment of $\$ x^{4}$.

More complicated series of actions require a series of messages to be passed. For example, if a household decides to buy a new home, the household agent calculates how much s/he can borrow and sends a message to a bank requesting a mortgage loan. The bank then reads this message. Based on the information the household sent, the bank agent approves or rejects the loan request. Regardless, the bank sends a message to the household. If the message is "accept" the household responds to a developer by stating that the household agent wants to buy a house.

Implementation of the message-passing system is an important computational capability. Aspen is designed to run on the massively parallel Paxagon computer; hence, the agents in the model are distributed among the processing nodes of the computer. Each agent has a message queue containing incoming messages for the agent to read. When an agent sends a message, a toolbox routine determines whether the recipient is on the same node. If so, the message is immediately placed in the recipient's queve. If the recipient is not on the same node, the message enters a holding area for messages to be routed from the sender node to the recipient node. At the end of the stage, the holding areas are emptied, and the contents are shipped in packets to the appropriate nodes. Alf messages going from one particular node to another particular node are placed in the same packet. At the beginning of the next stage, the packets arriving at each node are broken, and their messages are distributed (using a second toolbox routine) into individual agent quewes. When they are processed, recipients read the messages (using another toolbox routine).

In this way, each stage has at most only one cross-node communication between a given pair of nodes. (If no agent on the sending node wishes to send a message to an agent on the recipient node, no cross-node communication occurs.) Communicating between nodes on the Paragon requires a significant amount of time and could degrade the performance of the run.

\section{Initializing Values and Creating Parameters}

Many agent decisions in Aspen depend on the agent's current state. For example, a householder agent's consumption decisions depend on family size, current income, savings account balance, bond holdings, etc. Certain values must be initialized. When an

\footnotetext{
"Every cash debit is balanced by a credit (and vice versa). This provides an accounting check that ensures the model runs properly and that the total amount of money in the economy is conserved.
} 
Aspen run begins, each household is assigned a savings account balance, an initial bond holding, and an age for the household head. These kinds of assignments are done randomly using pre-selected distributions. For instance, for initial savings levels each household draws its value from an exponential distribution with mean $\$ 800$. In this way, Aspen simulates a heterogeneous population.

For almost any quantity, the user can enter unique values. Otherwise, default values are used.

The above discussion applies also to the numerous parameters of the models, (such as the frequency of automobile breakdowns, the length of a standard mortgage, or the percentage of savings that constitutes the reserve requirement at a bank).

See Appendix $A$ for a list of initialization values and parameters together with respective default values. Default values were used in the runs discussed in the Results and Discussion section.

\section{Agents}

This stbsection reviews the decision rules for agents from each of the different classes. Figure 1 illustrates the Iogical relationships between the various agent classes.

\section{Households (individuals)}

Most Aspen agents are households (individuals). Household agents generate most of their income through employment. Employers are from one of the four finm types or from banking, real estate, capital goods production, or the goverment sector. The householder obtains a job by accepting a job offer message. The employer pays a salary until the householder/employee givits or is fired. If at any time a householder is not employed, this agent collects a welfare payment from the govemment. The payment amount depends on family size. A senior citizen may collect social security payments. Other revenues a householder may generate include interest payments from bonds and savings accounts as well as shares of company profits (see Finms). The householder pays a flat-rate income tax on all income. 


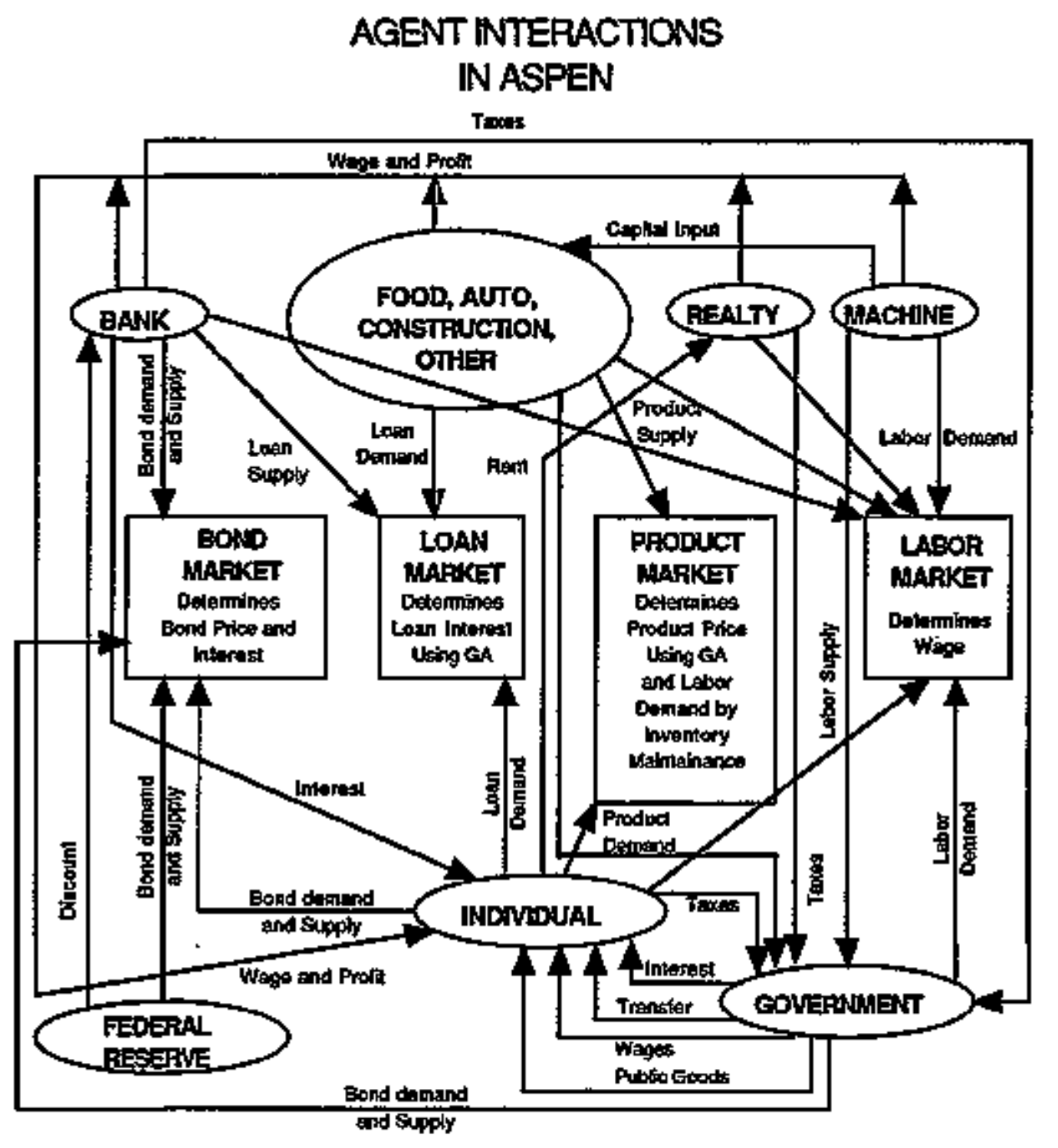

Figure 1. Aspen Agent Interactions. 
The householder consumes four types of goods each day: food and other nondurable goods, as well as goods and services related to transportation and shelter. A householder agent's goods consumption is not determined in the usual way; there is no exogenous utility function that is maximized over all feasible consumption bundles. Rather, Aspen uses simulation techniques and teasonable rules of thumb.

Demand for food is assessed daily based on family size. When this demand has been determined, the household agent identifies a suitable food fim. The agent first consults a list of food prices; each food firm broadcasts price-per-unit messages daily.

If firm $f$ offers food for price $p(f)$, the household agent buys from this food with a probability $k^{*}[p(f)]^{-q}$

where $q=$ a given exogenous parameter and

$\mathbf{k}=$ a nomalizing constant.

In words, the lower $p(f)$ is in relation to other firms' prices, the greater chance the household has of satisfying its demand by buying from $\mathrm{f}$.

A household consumes other nondurable goods in the same way, except that demand is calculated as a given percentage of income minus food expense divided by the average industry-wide price of other nondurable goods.

As long as the family car nuns properly, a household has no transportation demand. However, with a given daily probability, the car may break down and the household agent must try to buy a new car. The agent identifies a suitabie automobile producer by using the criterion of price-per-auto unit. This process resembles how the agent deternined where to buy food. With sufficient savings, the agent can buy an expensive car, that is one for twice the unit price. Otherwise, the agent applies to a bank for an auto loan; the agent will identify the bank offering the lowest loan-interest rate. The loan amount is based on payments that are no more than $10 \%$ of income during a five-year loan ${ }^{3}$ The loan amount determines the number of automobile units bought. Thus, market automobile demand is a function of personal income, personal savings, and interest rates.

Demand for housing is detenmined similarly. Each household is initially designated as renter or homeowner. ${ }^{6}$ The renter pays the realtor agent a given percentage of income as rent every day. In addition, the renter has a probability each day of wishing to buy a new home ${ }^{7}$. The homeowner has a different probability of wishing to buy a bome

\footnotetext{
${ }^{5}$ This is true if the loan amount plus cash-on-hand will buy no more than two units of auto. If it will bory more, the consumer will buy a two unit car, this payunent will be less than . I of the consumer's income. ${ }^{6}$ This is done during the 30 th day of a num, according to (a) the age of the household head, and (b) the employment status of the housetrold head at that time.

This probability depends on mortgage faterest rates.
} 
improvement. ${ }^{8}$ The renter and homeowner choose a developer to build and a bank for the mortgage or home improvement loan based on the prices the developer and banker agents are charging for services.

Besides paying to consume these four goods (food and other nondurable goods, plus goods and services nelated to transportation and shelter), a household agent allocates its remaining assets to pocket cash, savings (depositing or withdrawing money into a family savings account at one of the banks), and investment (buying or selling goverument bonds. The amount of pocket cash is an exogenous constant. The fraction of the remaining funds used to purchase bonds is based on a given increasing function, where the independent variable is the total amount of remaining assets and the dependent variable is the percentage of these assets that should be invested in bonds ${ }^{9}$ The amount remaining after bond purchases is placed in a savings account.

Every 90 days a household agent may move family savings to another bank. The householder is more likely to do so if other banks are offering a higher interest rate.

\section{Firms}

All four types of Aspen firm agents use capital and labor to produce goods. In particular the firms all have production functions of the form $y=c K^{3} L^{b}$

where $y=$ the output of goods on a given day

$K=$ the number of machines on hand in the factory

L = the number of employees.

The quantities $a, b$, and $c$ are constants, with the value of $c$ the same across firms in the same industry.

A firm agent can vary production by changing $\mathrm{K}$ or $\mathrm{L}$. Once annually, a firm may take out a business loan to buy a new machine (thereby increasing $K$ by 1 ). To make this decision, the firm weighs the value of increased production against the extra expense of the machine plus loan costs. In addition, every day the firm may hire or fire workers. This decision results from comparing recent average daily demand with the current inventory level. If the quantity (inventory minus demand) is less than a certain constant, the firm issues job offers; if inventory minus demand is greater than a certain other constant, the firm issues pink slips.

Wages in this simple model are constant across all firms in all industries.

\footnotetext{
8 The parameters are set so, if interest rates were constant, total housing denaand (that is, demand for new homes plus derand for bone improvements) would temain constant over time, even as renters become homeawners.

"A future model will make the more realistic assumption that the savings/investment' consumption decision depends atso on the age of the household head.
} 
Aspen uses GALCS to simulate a finn setting product prices. A fimm agent determines four trends daily: (a) whether product price has been recently increasing or decreasing, (b) whether sales have been recently increasing or decreasing, (c) whether profits have been recently increasing or decreasing, and (d) whether prices are higher or lower than the industry average. Based on answers to (a) through (d), the firm finds itself in one of 16 states.

The GALCS assigns a probability vector $\left(\mathrm{p}^{\mathrm{D}}, \mathrm{p}^{\mathrm{I}}, \mathrm{p}^{\mathrm{C}}\right)$ to each state,

where $\mathrm{p}^{\mathrm{D}}=$ the probability the firm agent will decrease a given price (by a certain exogenously specified amount ${ }^{10}$ ) the next time the firm enters the same state

$\mathrm{p}^{\mathrm{j}}=$ the probability the firm will increase the price

$p^{c}=$ the probability the firm will keep the price constant.

Upon entering a certain state, the firm agent decides how to change a given price by using the corresponding probability vector and choosing a random number. The agent then adjusts the vector according to how the price-change affects profits.

For instance, suppose at a particular time that for state $2,\left(\mathrm{p}^{\mathrm{D}}, \mathrm{p}^{\mathrm{t}}, \mathrm{p}^{\mathrm{C}}\right)=(.1,6,3)$. Suppose a fim enters this state and draws a random number that indicates the need for a price increase. Suppose further that as a result of increasing price, profits drop. The vector is adjusted to reflect this drop to $(15, .5,35)$. Thus, Aspen simulates the firm agent's leaming process. The agent learns that raising prices in state 2 was detrimental. As a result of an incorrect decision, the vector is adjusted to reflect a decreased probability of a price increase. The changed probability vector reflects the unlikelihood that the agent will increase prices upon re-entry into state 2 .

For more details on GALCSs and GALCS results from Sandia nuns, see GALCS: Further Discussion.

Finally, a firm must pay taxes on any profits and social security taxes on the payroll. There are three options at present for distributing after-tax profits. First, if a firm is solely owned, all after-tax profits go to a designated household. If the tirm is worker owned, profits are divided equally among all current employees. Finally, in the spirit of general equilibrium models (see Varian, 1978, p. 163), profits may be disbursed equally to all households in the entire econony. This last option is the default used for all firms in all cutrent runs of this study.

\section{Banks}

Aspen banks have four functions: (a) to maintain savings accounts for households, (b) to buy/sell government bonds, (c) to make loans, and (d) to hire a small workforce.

\footnotetext{
${ }^{10}$ These amounts are given listed under Price Changes in Appendix A-Firms: Food; Firms: Other nonDurables; Automakers; and Housing Developers.
} 
As mentioned above, households can switch savings banks once every 90 days. Daily every bank decides on a savings interest rate by taking the effective yield on bonds (the dividend amount divided by the bond price) and multiplying by $4 / 5$. In the current model, all banks offer the same interest rate, so all are expected to have roughly the same number of savings accounts.

Each day banks must check to make sure that they have a reserve amounting to $3 \%$ of their total savings account deposits plus another $1 \%$ discretionary reserve. If they exceed these requirements, they atternipt to buy bonds with the excess. On the other hand, if they do not meet this requirement, not only do they attempt to seil bonds, but they also must apply for discounting from the federat reserve agent.

Also, banks process loans. A bank loan interest rate is the sum of two terms: The first is a function of bond prices and the bank's observed defauth rate on loans. The second is generated using a GALCS." Upon receiving a loan application, the bank agent rejects the loan if (a) the payment amount is too high compared to the applicant's income, (b) the defailt rate on recent loans has been too high, or (c) the applicant has defaulted on a loan recently. Otherwise, the bank agent accepts the application.

Finally, banks maintain a small workforce; the size is a function of total bank assets. The bank pays income and payroll taxes.

\section{Government}

Every day, the Aspen government agent coliects taxes (income, sales, and payroll taxes), pays assistance to the elderly and the unemployed, pays dividends on any outstanding bonds, and employs a given percentage of the poputation (default: $25 \%$ ). If at the end of these activities, the sum of the revenues is less than the sum of the expenditures, the govenment agent issues bonds. Bonds have no maturity date and pay a dividend of 5 cents per unit per year. Initially bonds are priced at $\$ 1 /$ mit (the effective yield of bonds is $5 \%$ ), but bond prices are allowed to change to reflect the bond market.

The Aspen user may simulate an expansionary or contractionary government fiseal policy by changing tax rates ox the rate of govenument expenditure.

\section{Financlal Market}

Every day, as described above, the government, households, and banks tach decide how many bond units they wish to issue, buy, or sell. These orders are sent to a special Aspen agent calied the financjal market agent. When all orders have been counted, the market agent determines whether there axe mote buy orders or sell orders. The market agent then sends the result to the federal reserve agent, for use if the federal reserve is conducting an

\footnotetext{
IJ The bark's GALCS is similar to that described for \& finn setting prices; the bank loan interest rate is substituted for product price and total amount of loans is substituted for product sales.
} 
exparsionary, contractionary, or stabilizing monetary policy (see Federal Reserve). This may or may not induce the federal reserve to send an order to issue, buy, or sell bonds.

When all orders are counted (including those of the federal reserve), the market responds. Suppose there are more buy than sell orders; that is, the dollar value of buy orders is greater than the dollar value of sell orders. In this case the market agent fills all the sell orders, fills the same fraction of each buy order, and raises the bond price. However, if there are more sell than buy orders, the market agent fills all the buy orders, fills the same fraction of each sell order, and lowers the bond price.

\section{Federal Reserve}

The Aspen federal reserve agent performs many of the functions the real Federal Reserve performs. Fist, if a bank camnot meet the reserve requirements, the bank agent sends a message to the federal reserve. The federal reserve discounts at an exogenously given (by the user) discount rate. Also, if the govemment wishes to issue bonds but has no buyers, the federal reserve agent buys these bonds.

Finally, the federal reserve agent can implement either expansionary, contractionary, or stabilizing monetary policy after the financial market agent reports on the relative amounts of buy and sell bond orders. If the federal reserve agent is conducting expansionary policy and has a surplus of sell orders, the federal reserve sends the market a buy order. Conversely, if the federal reserve agent is conducting a contractionary policy and has a strplus of buy orders, the agent sends the market a sell order. Finally, if the federal reserve is conducting a stabilizing (or fixed interest) policy, the federal reserve sends buy and sell orders to maintain a constant bond price.

The Aspen user has the option of conducting expansionary, contractionary, stabilizing policy, or none of these policies on behalf of the federal reserve.

\section{Realtor and Capltal Goods Producer}

The realtor agent collects rental payments from nonhomeowners and pays a staff of employees. Staff size is proportionate to the number of renters. The capital-goods-maker agent produces machines and has a labor force whose size depends on the number of orders.

Neither of these agents are firms in the true sense because their prices are fixed and they have no competitors. However, both agents eam profits, pay taxes, and disburse after-tax profits in a manner similar to other firms (see Firms). 


\section{Results and Discussion}

The following discussion summarizes economic results, nun times and agent locations, GALCS, and the correlation of GALCS to prices that are dictated by theory.

\section{Economic Results}

Appendix B contains some Aspen results. These results are from a model with

- 1,000 households

- 3 food producing firms

- 2 other nondurable goods producers

- 2 automakers

- 2 housing developers

- 2 banks

- 1 of all other agent types.

Initializations and parameter values are shown in Appendix A. We first ran the model for 2,000 periods (under a stabilizing monetary policy that a federal reserve agent implemented). This run provided the GALCS probability vectors (that is, the vectors $\left[\mathrm{p}^{D}\right.$, $\mathrm{p}^{\mathrm{I}}, \mathrm{p}^{\mathrm{C}}$ ] from the discussion in Firms) adjusted to realistic values. We then ran the model 20 times (10 times under an expansionary monetary policy and 10 times under a contractionary policy) for the following 3,000 periods. Thus, the results displayed are all 10-run sarnple averages.

In Appendix B, Graph B1 records the effects of an expansionary versus a contractionary federal reserve policy on loan interest rates. Economic theory dictates that given a contractionary policy, bond prices should be lower because the federal reserve is selling bonds. The lower price in turn implies that bonds have a higher "effective yield" as an investment. Hence, the banks will invest more in bonds and less in other investments, such as the giving out of loans. This lowered supply of bank loan money implies that we expect the loan interest rates to increase. This is in fact exactly what Graph BI shows.

Graphs B2, B3, and B4 illustrate the secondary effects of loan-rate increases. An increase in loan rates means consumers can afford less expensive autos and homes. Also consumers are less likely to purchase a home. Reduced sales imply increased inventory, reduced employment, and reduced income. Graph B2 illustrates these observations. Also, with higher interest rates, firms are less likely to make new investments in capital machinery. Hence, productivity, production, and profits suffer. In the Sandia model, lower profits mean lower household incomes and dropping consumer demand. Graph B3 illustrates that reduced demand causes prices to drop. This, combined with lower production and consumption gives lower nominal gross national product (GNP), as shown in graph B4. 
Finally, we successfally reptoduced on our model some of Modigliani's (1972) experiments on the $\mathrm{FMP}^{\mathrm{l2}}$ model. Specifically, we increased government spending by $\$ 1,000$ per day for three years and observed the multiplier effects on the economy.

The resultant government expenditure multiplier is not properly defined untess we specify the monetary policy to be followed by the federal reserve over the period Hence, Sandia performed the experiment under two monetary policy scenarios and noted the difference in run ottputs. The first scenatio had the federal reserve agent conduct a stabilizing monetary policy of keeping bond price at \$1 (see Federal Reserve); the second scenario had the federal reserve agent conduct a fixed money supply policy (that is, the agent bought a constant number of bonds each period). Unlike the first scenario, the bond price in the second scenario was allowed to change.

Graph B5 displays a 10-run average of nominal GNP for the Sandia model in the stabilizing case. The nominal GNP is shown with and without the $\$ 1,000 /$ day fiscal expansion (described immediately above). Graph B6 illustrates the same for a constant money supply case. Comparing these two graphs reveals much greater effect on nominal GNP in the stabilizing case than in the fixed money supply case. Modigliani also obtained this intuitive result.

Graphs B7 and B8 show the same effect on real (inflation-corrected) GNP.

Graphs B9 and B10 illustrat these effects quantified for govenment expenditure multipliers. These quantifications almost duplicate Modigliani's findings. The multiplier on nominal GNP reaches a value of close to 4 by the fifth quarter under stabilization. However, the multiplier is much smaller under the fixed money supply rule. In the latter case, the increase in bond interest rate reduces increased income. This "crowding out" is quite pronounced in both the nominal GNP and real GNP numbers.

A change in government spending affects bond and loan interest rates. Increased government expenditure implies more deficit and, therefore, an increase in bond supply. In the fixed-money-supply case, this increased deficit and bond supply should cause ant increase in the interest rate for bonds. Graph B11 demonstrates this.

Regarding loan interest, since the banking industry is highly oligopolistic, all banks look at a common signal (the bond price) to determine rates. As bond prices drop, bank loan interest rates rise. Hence, in the fixed-money-stpply case, the fiscal expansion should lead to an increase in loan interest rates. However, in the stabilization case when the bond price is constant, Ioan interest rates should stay relatively constant. Graph B12 supports this theory.

Finally, some further results are presented for the stabilization case. Graph B13 shows the effect of increased govemment expenditure on nondurable-goods consumption,

${ }^{12}$ FMP stands for Federal Reserve - MIT - University of Rennsyivania. 
average price level, home sales, and the unemployment tate. The effect of stabilization on the unemployment rate is substantial. This study inquired if the initial unemployment rate affected the multipliter for nominal GNP. Graph B14 (the result of that inquiry) indicates that the multiplier is higher if the initial unemployment level is set at $10 \%$ than if the initial unemployment rate is set at $5 \%$. Again, this finding duplicates a Modigliani test result from the FMP model.

\section{Run Times and Agent Location}

This study also examined how processing time for an Aspen nun varies as a function of the number of Paragon computer nodes. In general, the rum time can be broken into (a) time needed to send messages between agents on the same node, (b) time needed to send messages between agents on different nodes, and (c) time needed for agents to carry out all other tasks. In general, (a) is insignificant. Also, as the number of nodes increases (but the number of agents $n$ stays constant), (b) increases because there are more nodes and more cross-nodal packets (see Mechanics of the Model) to be sent during each stage. At the same time, (c) decreases because of the increased ability to compute in parallel. In fact, if $x$ represents the number of nodes, the run time (per stage) can be estimated as $\beta x+\gamma n / x$ where $\beta$ and $\gamma$ are constants associated with (b) and (c) respectively, with $\beta \ll \gamma$. ${ }^{13}$

The function $\beta x+\gamma d / x$ is convex with a unique minimum. Given a certain agent set, there should be an optimum number of nodes on which to run a problem. The Sandia study verified this. This study made a series of runs, all using 1,000 households and the default values listed in Appendix A. Only the number of nodes were varied, with two nens for each different node number. These results (see Appendix C) indicate that (a) run times are remarkably consistent from rom to rom if the node number is constant, (b) run time is linear in the number of time steps, and (c) the optimal number of nodes is approximately 37 . These same runs were made using 2,000 households and then 5,000 households. The optimal number of nodes rose to the 20 to 25 range.

Agent distribution on the nodes was examined when the node number is fixed. Government, federal reserve, and all bank and firm agents might seem appropriately placed on the same node. The remaining nodes might seem best dedicated to household agents because households do not send messages to one another. This arrangement would minimize the number of cross-nodal packets (see Mechanics of the Model).

\footnotetext{
${ }^{3}$ Here 3 represents (a constant multiplied by) the average time to send a cross-node communication, and $\gamma$ is the time for an agent to penform all activities of a stage. The expression depends on most nodes containing only bousehold agents, and kousehold agents not sending messages to one another in the current version of Aspen. If we were to develop a model in which housebold agents do send messages to one another, then the correct expression would be $\beta x(x-1)+\gamma / x$. This would not change the loglc in what follows.
} 
However, in that case the node with nonhousehoid agents would take far longer to process all members than would any other node. In Aspen all nodes must finish. processing all members before the run can proceed to a new stage. Hence, the model would run more slowly; time would be wasted as the household nodes waited for the nonhousehold node to finish.

In the current version of Aspen, the government and federal reserve agents are placed on the first node; the firms and banks are distributed over the second, third, and fourth nodes; and the households are distributed equally over all the nodes. This more balanced setup may alleviate the above problem, but at the expense of increasing the number of cross-nodal packets. In conclusion, further study is required to determine a method for efficient agent placement.

\section{GALCS: Further Discussion}

The Firms discussion did not fally explain how the quantitative changes in the probability vectors $p=\left(p^{D}, p^{1}, p^{C}\right)$ were computed. This study trief many variations. In all cases, each state was assigned a three-dimensional strength vector, initialized at $(100,100,100)$. When a firm enters a state and then raises, maintains, or lowers a price, the strength vector subsequently changes. When normalized, this vector becomes the new p. Sandia experiments used different procedures to change the strength vector.

One such procedure was to raise or lower the component of the strength vector associated with the corresponding action by 10 . Whether the component was raised or lowered depended on whether the action was successful. In other words, if the strength is at $(100$, $100,100)$ and the price is increased, then the new strength vector will be $(100,90,100)$ if profit level drops or $(100,110,100)$ if the profit increases.

A problem with this method is that, although strengths of $(10,20,30)$ and $(20,40,60)$ will compute to the same $p$, the probability vectors that occur after the next evaluation are different. A second problem is that the GALCS can become overtrained if the economy changes stiddenly after a period of stability. In this case, the probabilities for certain strategies might approach zero, making reaction to the new environment impossible for a firm.

In response to differing probability vectors, this study tried increasing or decreasing the strengths of the other components to maintain the sum of the strength components at 300 . In the example above where the profit level drops, the new strength vector was $(105,90$, $105)$ instead of $(100,90,100)$.

In response to overtrained GALCS resulting from a period of economic stability, this study restricted how high or low a strength component could go. 
Another issue was whether to consider first- or second-order effects to decide if a price change increased the profit. In certain scenarios (notably the expansionary or contractionary cases described in Economic Results), profits increased (or decreased) regardless of pricing strategy. Hence any strategy tried would be positively (negatively) reinforced, leading to somewhat unrealistic results. This led us to experiment with using a second-order condition on profits to determine success; that is a certain pricing strategy would get reinforced if and only if the amount of profit-increase increased.

Unfortunately, determining the second-order effects requires profit analysis over a period of time; this profit analysis uses observations that may have been taken under a different pricing strategy.

Finally, we tried linking the magnitude of the strength-vector changes to the magnitude of the profit changes. This avoided the problems described in the previous paragraph. The best results (vectors $p$ agreeing with our intuition about what firms should do in various states) were obtained using this linkage.

\section{GALCS and Prices: Final Observation}

Consider a two-food finm economy in which the firms behave as those described in the Firms section. The first food firm's expected profit can be estimated as

$$
\Pi_{1}=\left(p_{1}-C\right)^{*}\left(p_{1}^{-q} /\left(p_{1}^{-q}+p_{2}^{-q}\right)\right)^{*} a
$$

where

p) = price first firm charges

$\mathrm{P}_{2}=$ price second firm charges

$\mathrm{C}=$ wage/worker productivity ${ }^{14}$

$\mathrm{q}=$ demand exponent (see Household (Individuals).

$a=$ constant marketwide household demand for food (units).

Similarty, $\Pi_{2}$ can be expressed as the expected profit for the second finn. A two-person game may be described where the players are firms and the strategies are the prices the firms charge. Under steady-state demand conditions, a unique equilibrium of the game occurs when $\mathrm{p}_{1}=\mathrm{p}_{2}=\mathrm{q} C(\mathrm{q}-2)$. In fact, when Sandia ran a prototype version of Aspen (described by Pryor-Basu-Quint [1996]) with two food firms, prices hovered near these values. Here, the genetic algorithoms lead to prices dictated by theory.

I4 Worker profuctivity is defined as the quantity of goods produced per worker day. In the model in the

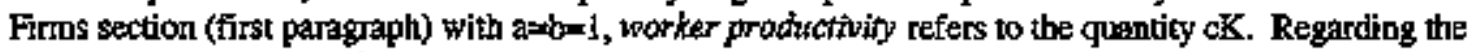
prototype model (where ftrms cannot buy capital), the quantity is a given constant. 


\section{Conclusion}

At its present level of development, Aspen is not yet ready to make quantitative forecasts. We acknowledge that certain sectors of the model need to be added or improved and that many parameters need to be estimated accurately. However, the economic results seem to validate the approach described here. Indeed, simulation models such as Aspen are expected eventually to complement the existing macroeconometric and CGE models, perhaps with superior analytic and forecasting capabilities. 


\section{References}

Bergmann, B. and R. Bennett, A Micrasimulated Transactions Model of the United States Economy, Baltimore: The Johns Fopkins University Press, 1986.

Modigliani, F., "The Channels of Monetary Policy in the FMP Econometric Model of the USA", in Modeling the Economy, Heineman Educational Books: London, 1976.

Orcutt, G., S. Caldwell, and R. Wertheimer, Policy Exploration through Microanalytic Simulation, Washington, DC: The Urban Institute, 1976.

Pryor, R.J., N. Basu, and T. Quint, "Development of Aspen: A Microanalytic Simulation Model of the US Economy", Sandia Report \#SAND96-0434, Sandia National Laboratories, Albuquerque, NM, February 1996.

Varian, H., Microeconomic Analysis, New York: W.W. Norton and Co, 1978. 
Intentionally Left Blank 


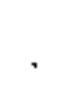




\section{APPENDIX A}

Initializing Values and Creating Parameters 


\section{Initializing Values and Creating Parameters}

\section{Initializing Values}

This study defines initialization as the assignment of an initial value to a variable that changes during a run.

\section{Households}

Age of household head: Uniformly distributed between 21.0 and 76.0 years

Employment status of household head: Unemployed

Savings: Exponentially distributed with mean $\$ 800$

Bond holdings: None.

\section{Fims; Food}

Cash assets: Uniformly distributed between $\$ 10,000$ and $\$ 50,000$

Number of machines owned: 100

Number of employees: 0

Price of food: $\$ 10$ per unit

Inventory: 1200 units of food.

\section{Fims: Other nonDurab/e Goods}

Cash assets: Uniformly distributed between $\$ 10,000$ and $\$ 50,000$

Number of machines owned: 100

Number of employees: 0

Price of other nondurable goods: $\$ 20$ per unit

Inventory: 10,000 units of other nondurable goods.

\section{Automakers}

Cash assets: Uniformily distributed between $\$ 100,000$ and $\$ 500,000$

Number of machines owned: 100

Number of employees: 0

Price of automobiles: $\$ 15,000$ per car unit

Inventory: No cars.

\section{Housing Developers}

Cash assets: Uniformly distributed between $\$ 100,000$ and $\$ 500,000$

Number of machines owned: 100

Number of employees: 0

Home price: $\$ 100,000$ per housing unit

Inventory: 10.0 umits of housing.

\section{Banks}

Loan interest rate (consumers): $9.0 \%$

Loan interest rate (businesses): $7.0 \%$

Savings interest rate: $4.0 \%$ 
Number of employees: 0

Government

Bond Price: \$1.00 per unit

Number of employees: 0

Federal Reserve

Cash assets: $\$ 50,000$

Realtor

Cash assets: $\$ 10,000$

Number of employees: $\theta$

Capilal Goods Producer

Cash assets: $\$ 10,000$

Number of employees: 0

\section{Creating Parameters}

To create a parameter, a value is assigned to a variable that cannot change during a run.

\section{General Variables}

Number of housebolds: 1,000

Number of food firms: 3

Number of other nondarable-goods firms: 2

Number of automakers: 2

Number of housing developers: 2

Number of banks: 2

Number of governments: 1

Number of federal reserves: 1

Number of reaity companies: 1

Number of capital goods producers: 1

\section{Households}

Family size: Unifomly distributed between 1.0 and 4.0

Income tax rate: $20 \%$ on income

Sales tax rare: $6 \%$ on purchases of automobiles and other nondurable goods

$0 \%$ on purchases of food and housing

Demand exponents (the parameters $\mathrm{q}$ described in the Initializing Values and Creating

Parameters section):

Food: 5.0

Other nondurable goods: 5.0

Automobile: 5.0

Home: 5.0

Loan interest rates: 8.0 
Automobile: 5.0

Home: 5.0

Loan interest rates: 8.0

Savings account interest rates: -8.0

Units of food demanded per day* $1.0 *$ family size

Units of other nondurable goods demanded per day:

0.4 * (income - food expense) / avg. other nondurabie-goods price

Auto failure rate: probability of .00018 per day

Public transportation cost (paid to government when a household agent does not own a working automobile): \$2 per day

Rent for nonhomeowners: $20 \%$ of income

Daily probability that renter desires new horne: $.00006+.001 *(1.0$ - bond price $)$

Daily probability that homeowner desires home improvement: $.00036+.001 *(1.0-$ bond price $)$,

Length of auto loan: 5 years

Payments on auto loan: .1 of income

Length of home loan: 30 years

Payments on home loan: .35 of income

Length of home improvement loan: 30 years

Payments on home improvement loan: .058 of income

Pocket cash not put in savings at the end of each day: $\$ 100$

Pocket savings not touched when buying autos or houses: $\$ 300$

Frequency of changing savings bank: every 90 days

Unemployment assistance: $\$ 50+\$ 5 *$ family size, per day

\section{Firms: Food}

Wage rate: $\$ 100$ per day

Income tax rate: $30 \%$ on profits

Payroll tax rate: $6 \%$ on wages

Disbursal of after-tax profit: Equally to all households in economy

Demand exponent (the parameter q described in Household (Individuals)):

Business loan interest rate: $\mathbf{8 . 0}$

Productivity parameters (for the production function $y=c K^{a} L^{b}$ ):

$$
\begin{aligned}
& c=.12 \\
& a=1.0 \\
& b=1.0
\end{aligned}
$$

Length of capital improvements business loan: 1 year 
Amount of capital improvements business loan: $\$ 1,000$

Inventory/demand ratio under which firm hires new workers: 2.5 to 1

(It then hires workers until production is 1.2 times average demand.)

Inventory/demand ratio over which firm fires workers: 5 to 1

(It then fires workers until production is 0.8 times average demand.)

Price changes (movements allowed each time GALCS iterates): $+\$ .50, \$ 0$, or $-\$ .50$

Firms: OthernonDurable Goods

Wage rate: $\$ 100$ per day

Income tax rate: $30 \%$ on profits

Payroll tax rate: $6 \%$ on wages

Disbursal of after-tax profit: Equally to all households in economy

Demand exponent (the parameter $q$ described in Households (Individuals)):

Business loan interest rate: 8.0

Productivity parameters (for the production function $y=c K^{*} L^{b}$ ):

$$
\begin{aligned}
& c=.06 \\
& a=1.0 \\
& b=1.0
\end{aligned}
$$

Length of capital improvements business loan; 1 year Amount of capital improvements business loan: $\$ 1,000$ Inventory/demand ratio under which fim hires new workers: 2.5 to 1

(It then hires workers until production is 1.2 times average demand.)

Inventory/demand ratio over which firm fires workers: 5 to 1

(It then fires workers until production is 0.8 times average demand.)

Price changes (movements allowed each time GALCS iterates): $+\$ .50, \$ 0$, or $-\$ .50$

\section{Automakers}

Wage rate: $\$ 100$ per day

Income tax rate: $30 \%$ on profits

Payroll tax rate: $6 \%$ on wages

Disbursal of after-tax profit: Equally to all households in economy

Demand exponent (the parameter $q$ described in Households (Indrviduals)): 
Business loan interest rate: 8.0

Productivity parameters (for the production function $y=c K^{\prime} L^{b}$ ):

$$
\begin{aligned}
& c=.00008 \\
& a=1.0 \\
& b=1.0
\end{aligned}
$$

Length of capital improvements business loan: 1 year Amount of capital improvements business loan: $\$ 1,000$ Inventory/demand ratio under which firm hires new workers: 3 to 1

(It then hires workers until production is 1.2 times average demand.) Inventory/demand ratio over which firm fires workers: 5 to 1

(It then fires workers until production is 0.8 times average demand)

Price changes (movements allowed each time GALCS iterates): $+\$ 200, \$ 0$, or $-\$ 200$

\section{Housing Developers}

Wage rate: $\$ 100$ per day

Income tax rate: $30 \%$ on profits

Payroll tax rate: $6 \%$ on wages

Disbursal of after-tax profit: Equally to all households in economy

Demand exponent (the pazameter q described in Households (Individuals)):

Business Loan Interest Rate: 8.0

Productivity Parameters (for the production function $y=c K^{\prime} L^{b}$ ):

$$
\begin{aligned}
& c=.000012 \\
& a=1.0 \\
& b=1.0
\end{aligned}
$$

Length of capital improvements business loan: 1 yeat Amount of capital improvements business loan: $\$ 1,000$ Inventory/demand ratio under which firm hires new workers: 2 to 1

(It then hires workers tintil production is 1.2 times average demand.) Inventory/demand ratio over which firm fires workers: 5 to 1

(It then fires workers unil production is 0.8 times average demand,) 
Price changes (movements allowed each time GALCS iterates): $+\$ 500$, $\$ 0$, or $-\$ 500$

\section{Banks}

Wage rate: $\$ 100$ per day

Income tax rate: $30 \%$ on profits

Payroll tax rate: $6 \%$ on wages

Disbursal of after-tax profit: Equally to all households in economy

Discount rate (for boxrowing from federal reserve): $5.5 \%$

Required reserve ratio: $3 \%$ of total savings deposits

Desired extra reserve ratio: $1 \%$ of total savings deposits

Consumer loan interest rate: $8.0 \%$ / (bond price * $(1.0$ - default rate) )

Additional consumer loan interest rate changes (movements allowed each time GALCS iterates): $+.02 \%, 0 \%$, or $-.02 \%$

Business loan interest rate: $7.0 \%$ / bond price

Savings interest rate: $4.0 \%$ / bond price

\section{Govemment}

Wage rate: $\$ 100$ per day

Number of job openings: 250 ( ( $25 \%$ of the number of households)

Dividend payment per unit of bond: 5 cents per year

\section{Realtors}

Wage rate: $\$ 100$ per day

Income tax rate: $30 \%$ on profits

Payroll tax rate: $6 \%$ on wages

Disbursal of after-tax profit: Equally to all households in economy

\section{Capital Goods Producers}

Wage rate: $\$ 100$ per day

Income tax rate: $30 \%$ on profits

Payroll tax rate: $6 \%$ on wages

Disbursal of after-tax profit: Equally to all households in economy

Employee productivity: .1 machine per worker-day 
Intentionally Left Blank 


\section{APPENDIX B}

Graphs Illustrating Study Results 


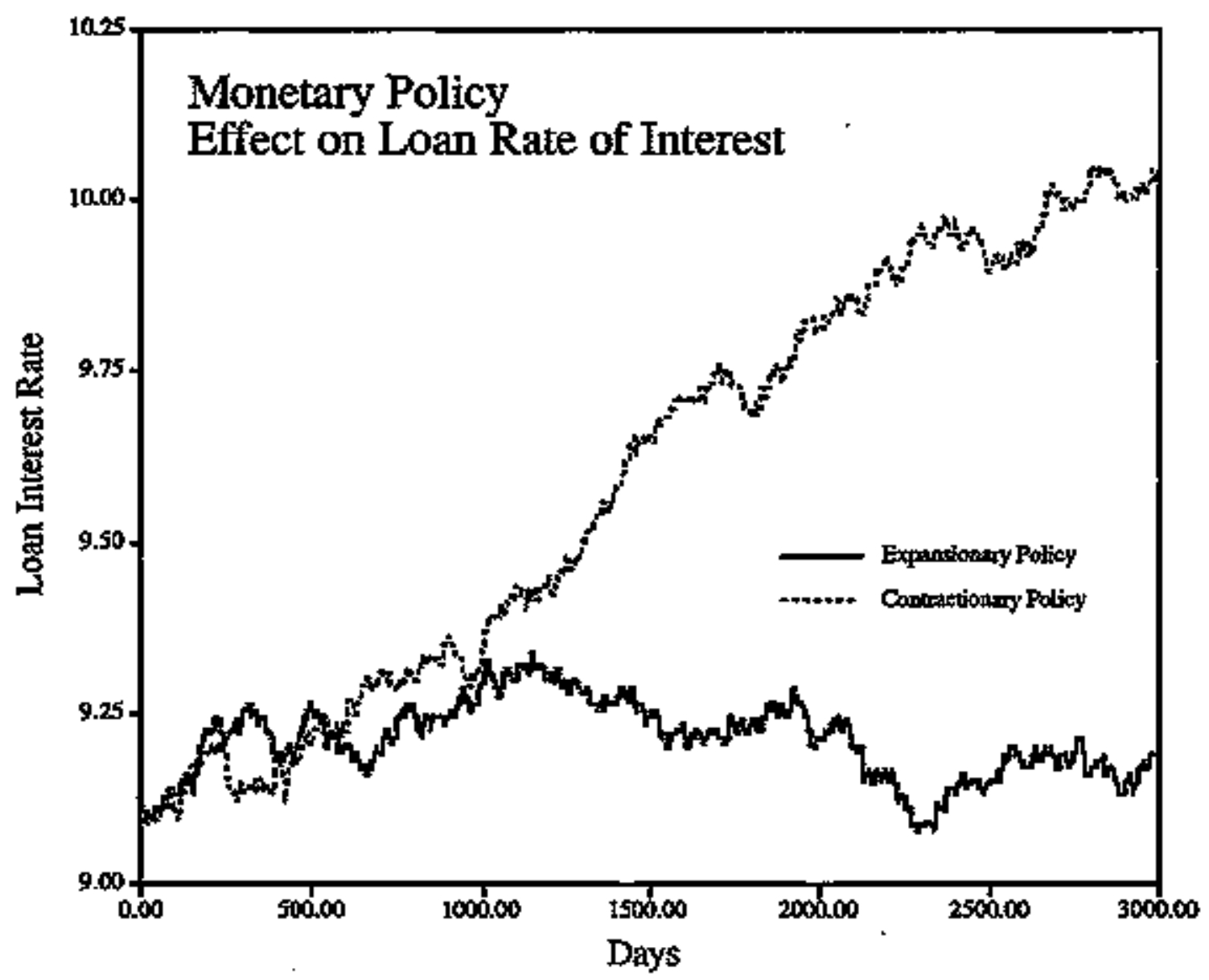

Graph B1 


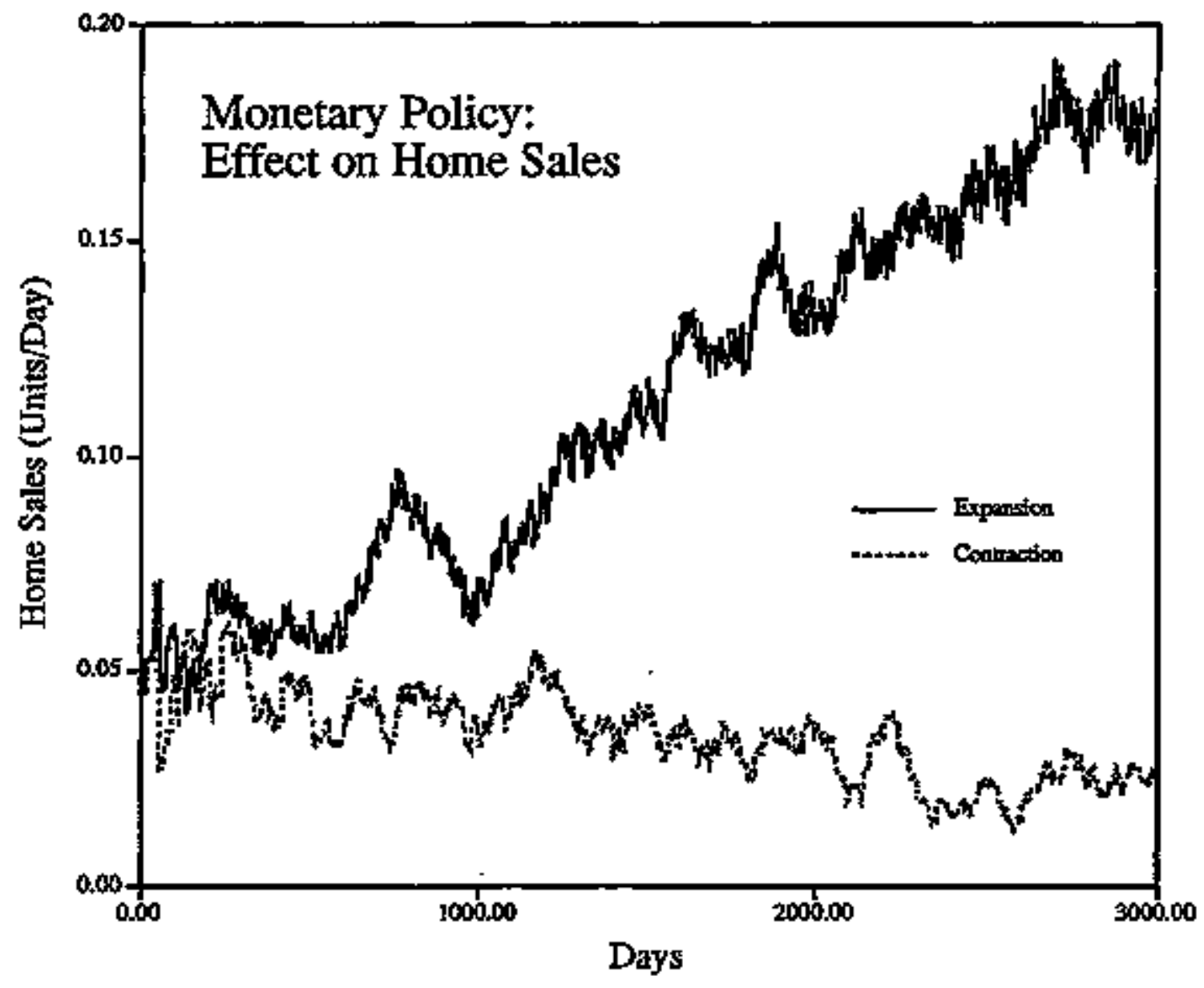

Graph B2 


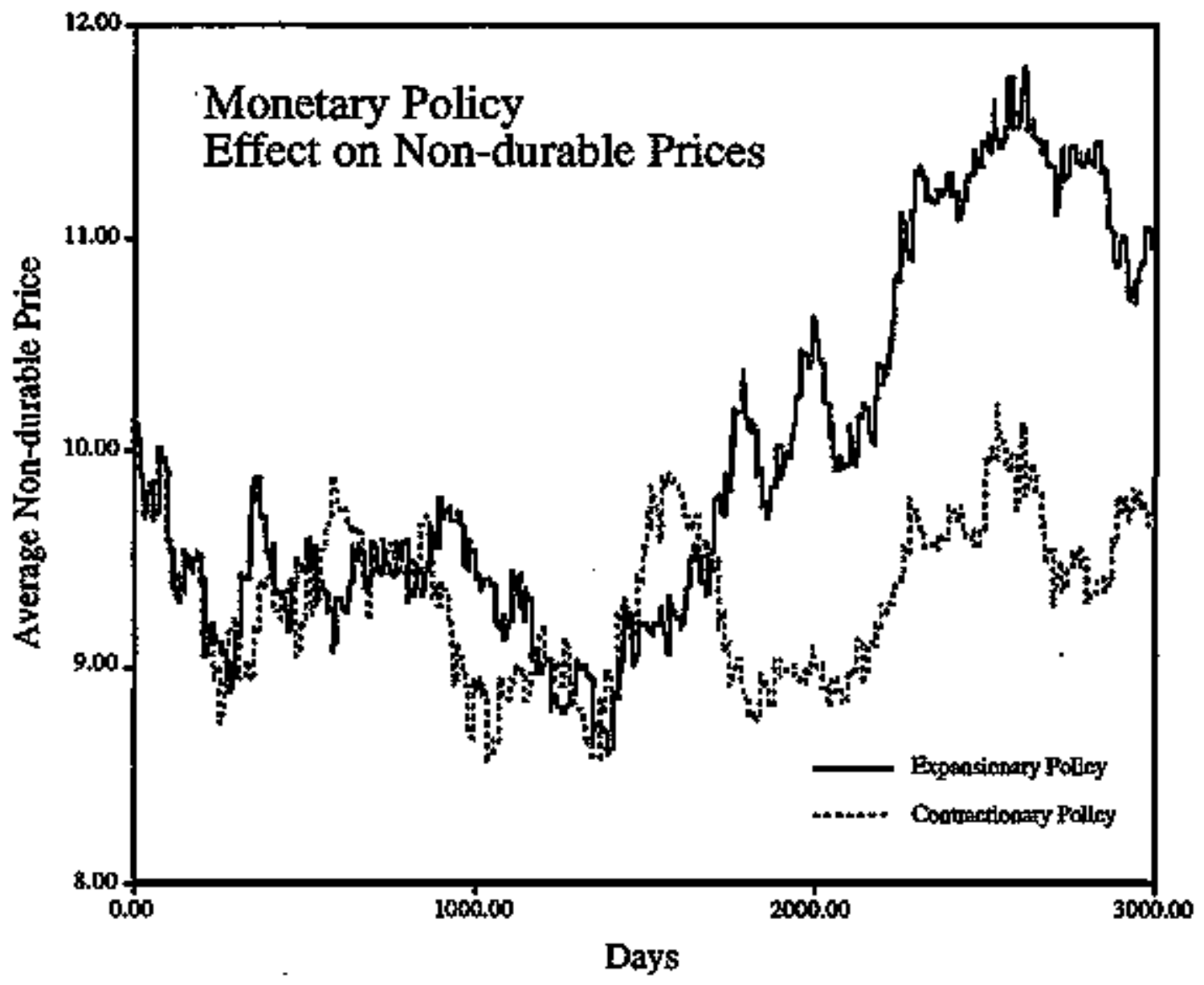

Graph B3 


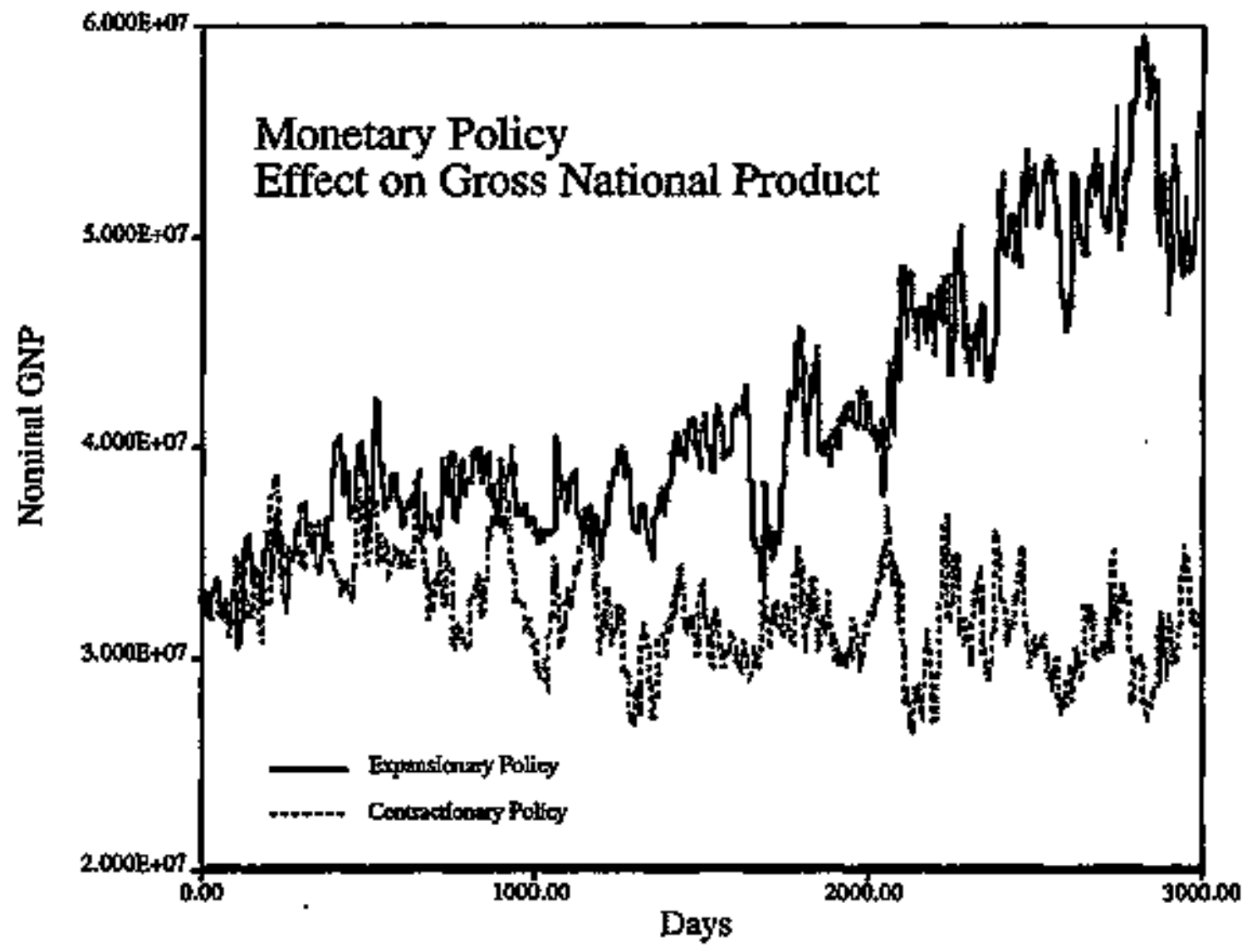

Graph B4 


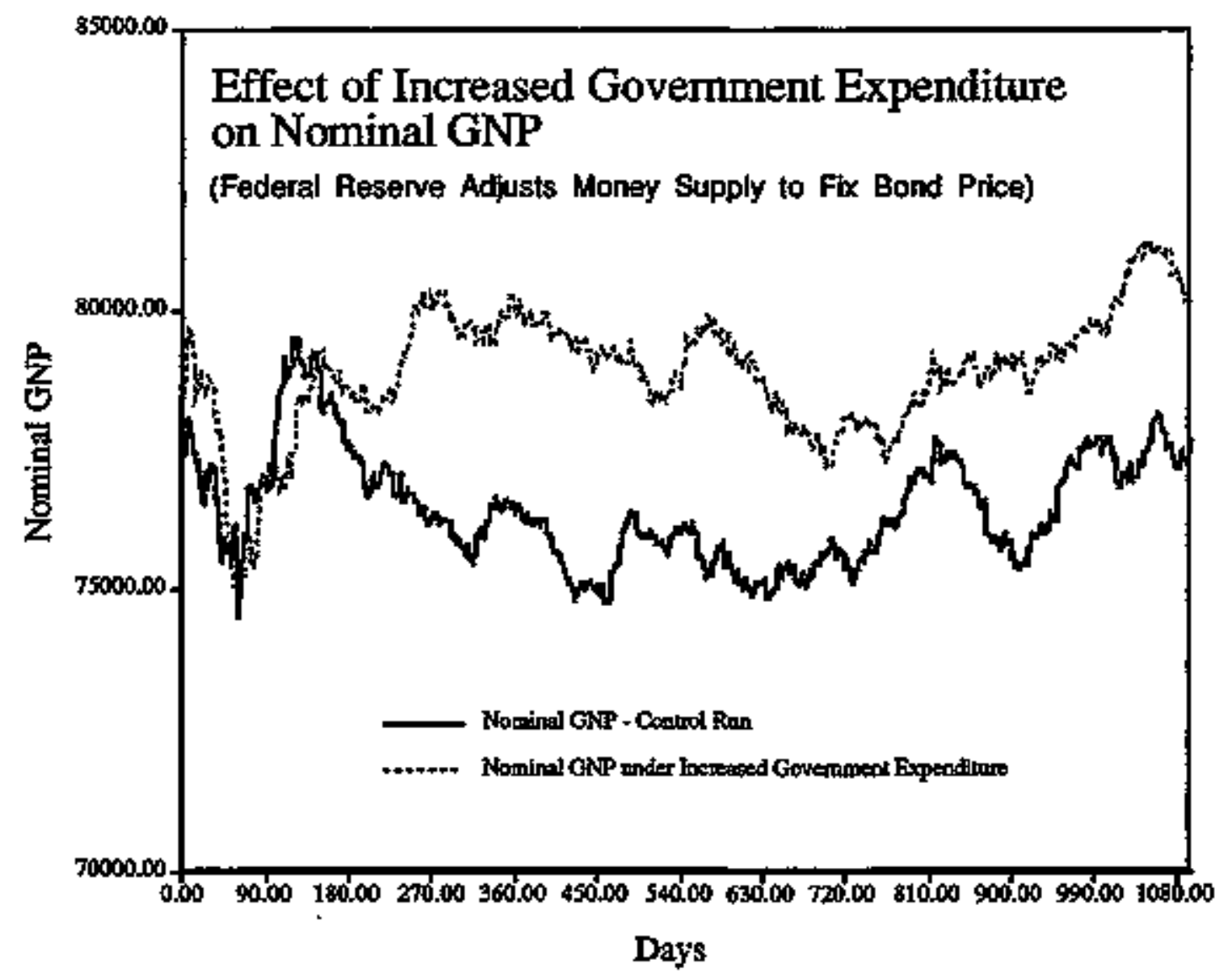

Graph B5 


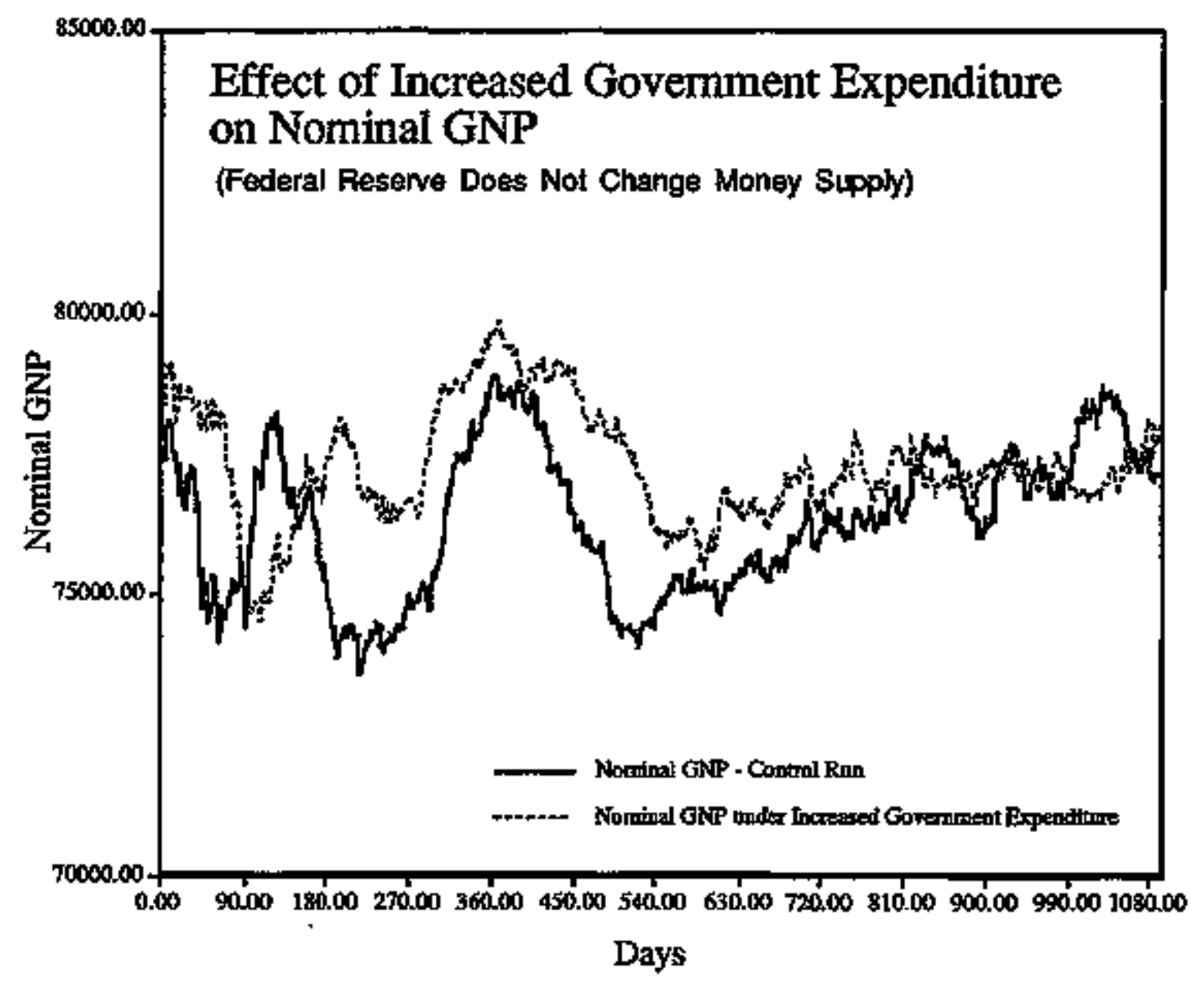

Graph $B 6$ 


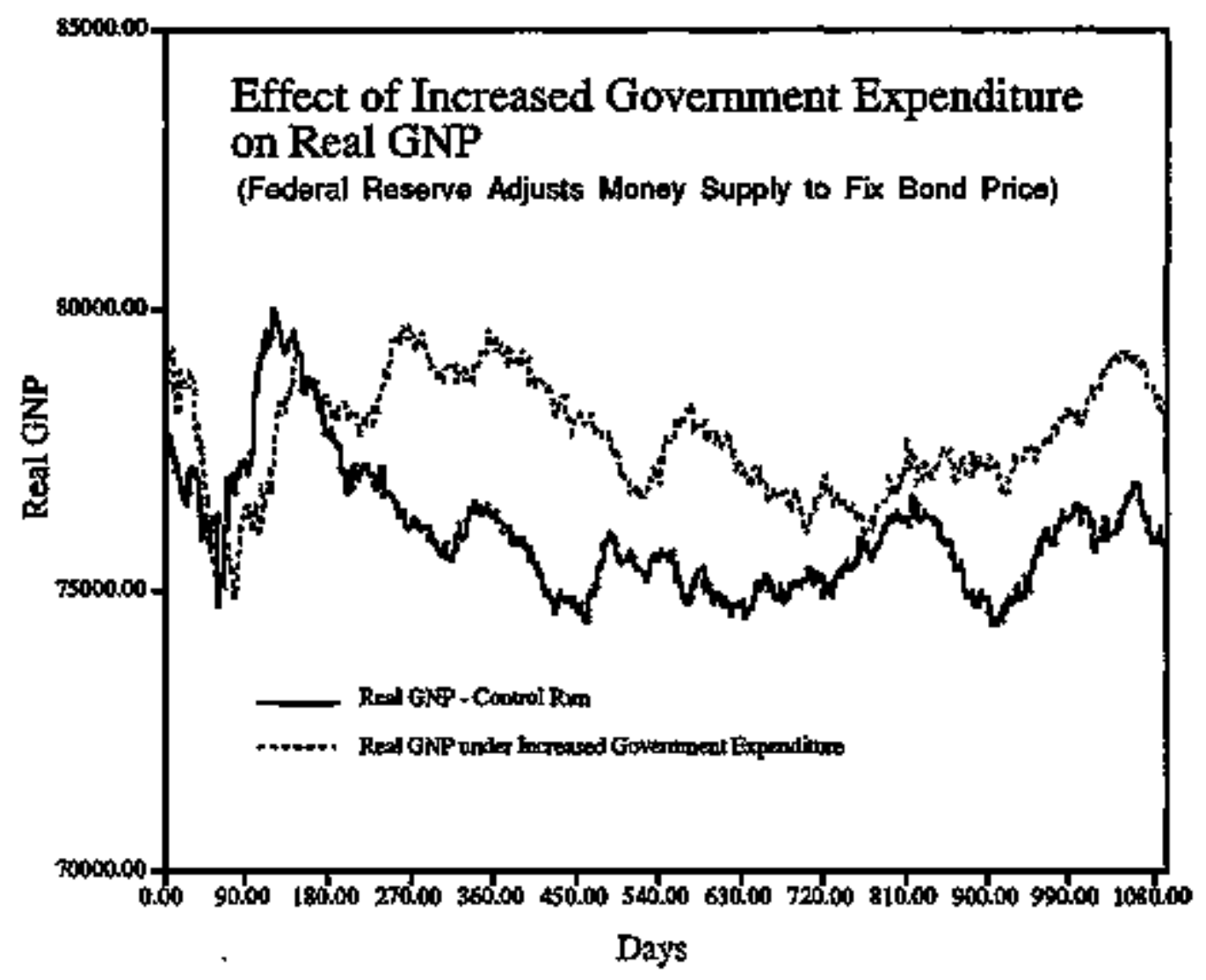

Graph B7 


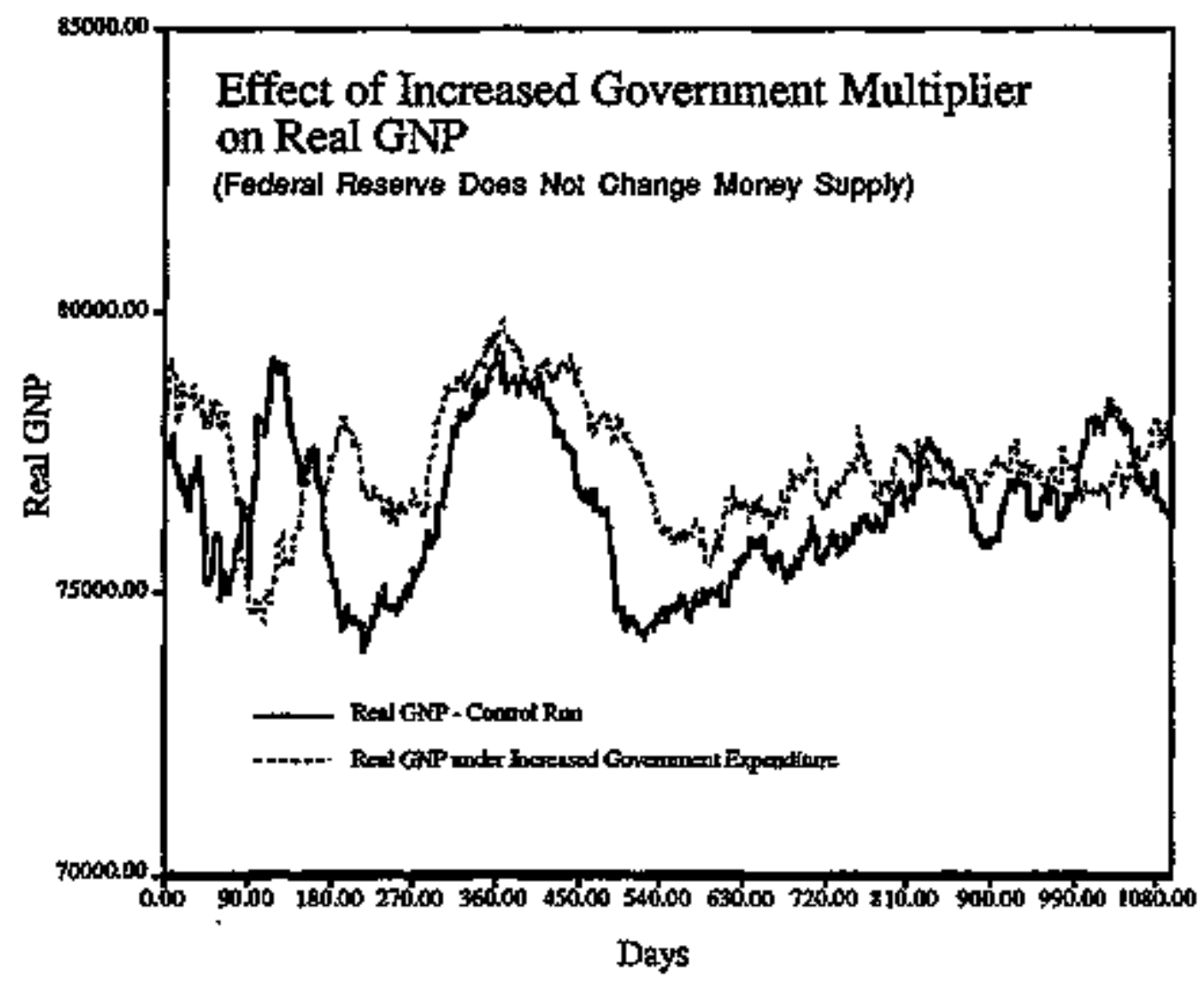

Graph B8

B-9 


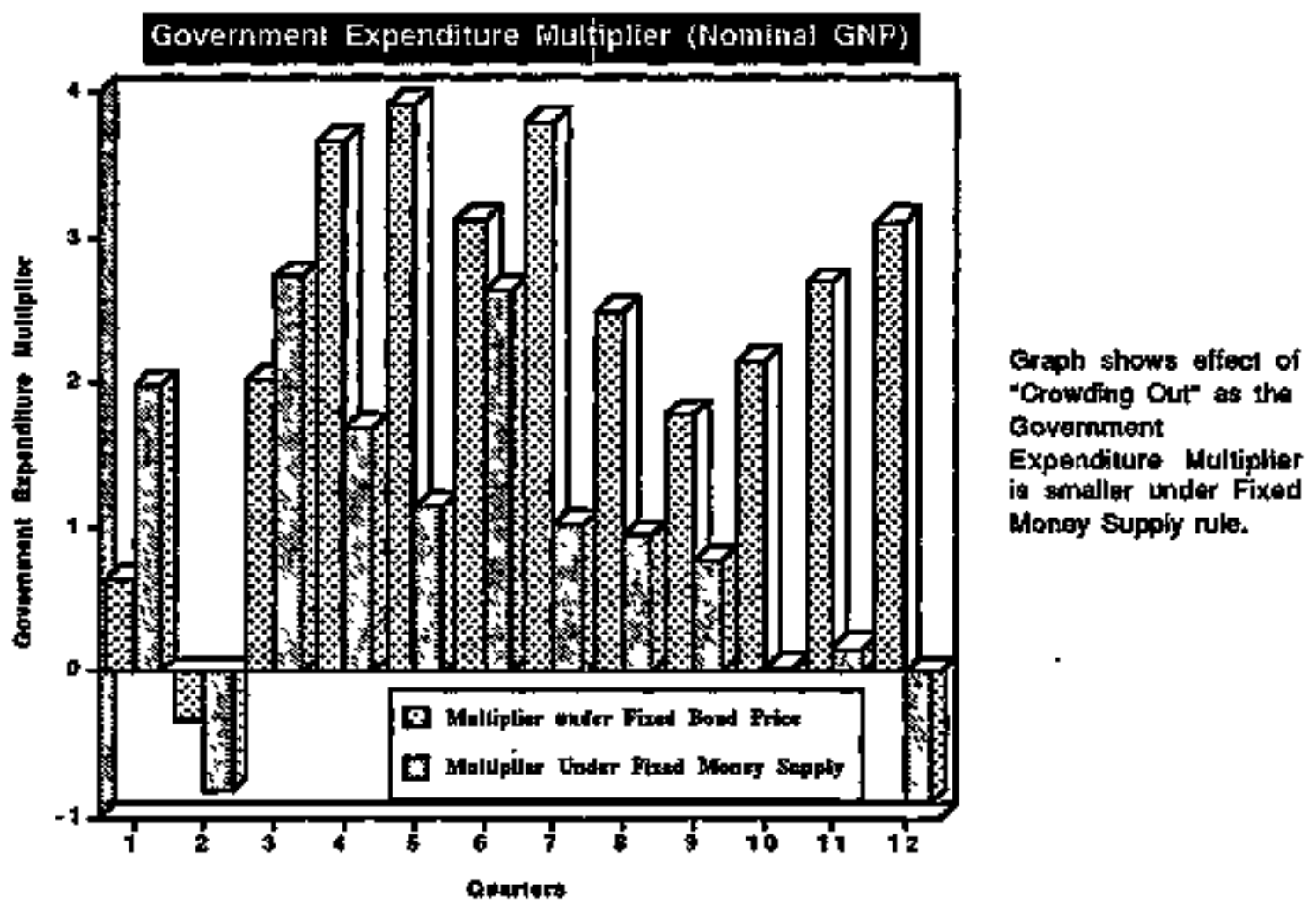

Graph B9 


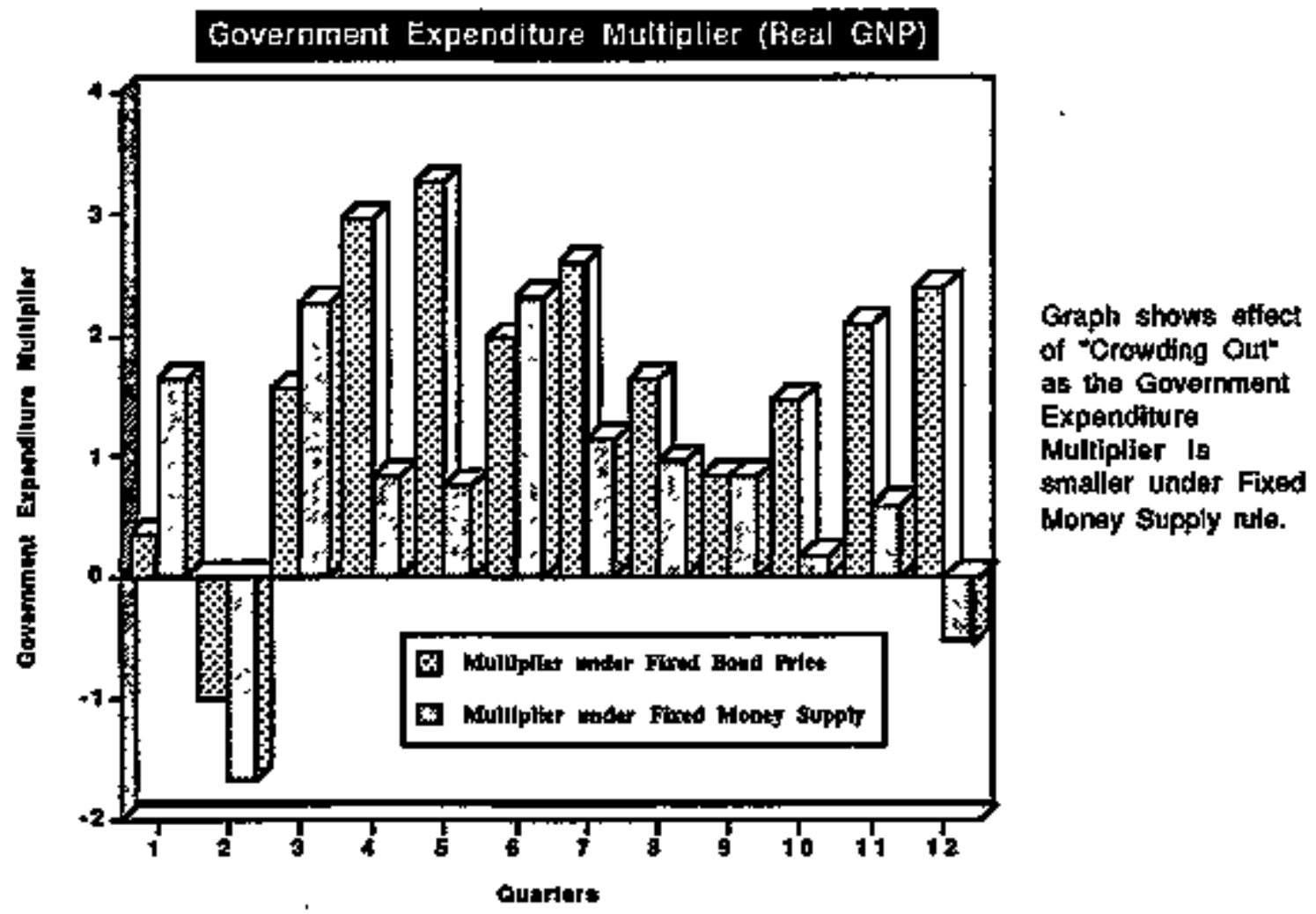

Graph B10 


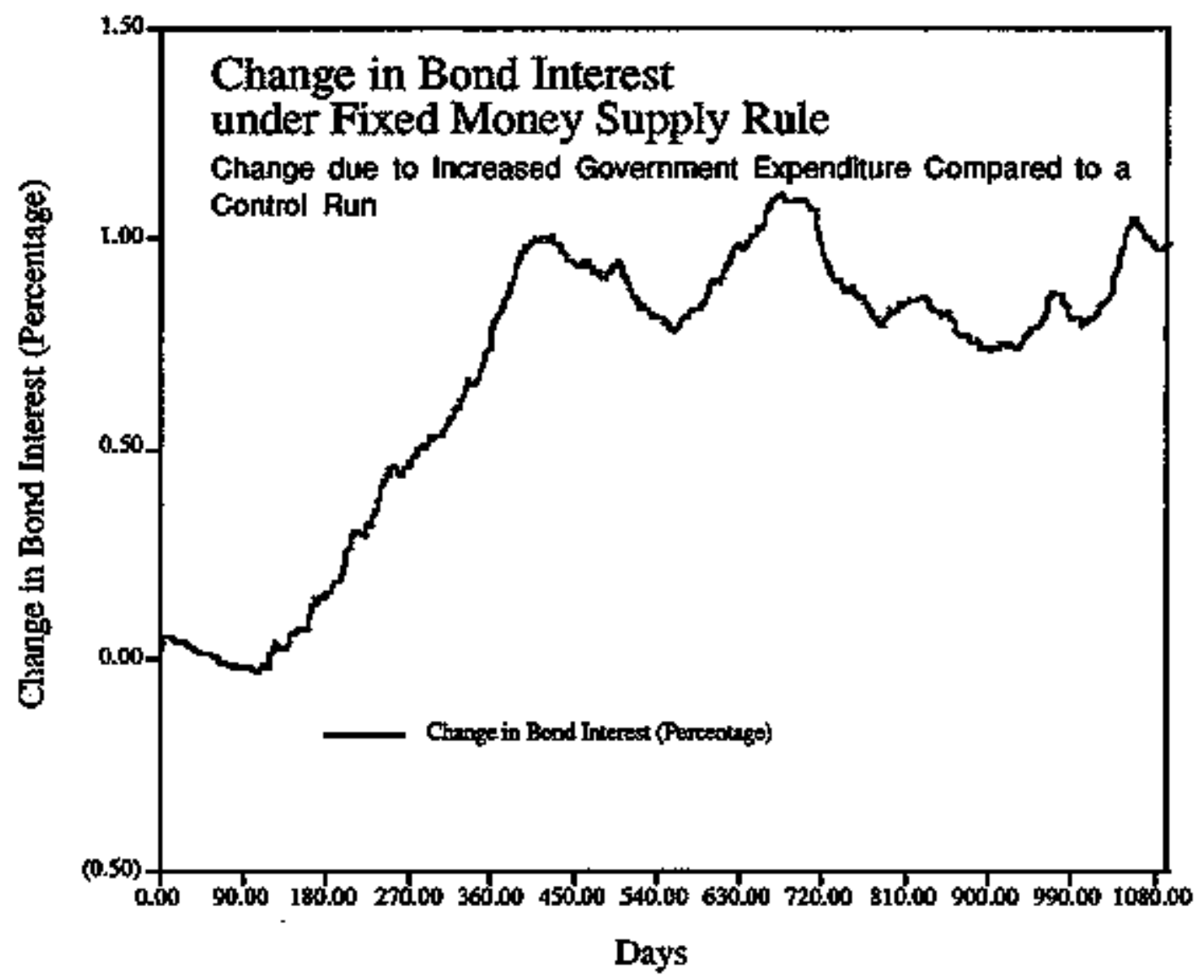

Graph B11

B-12 


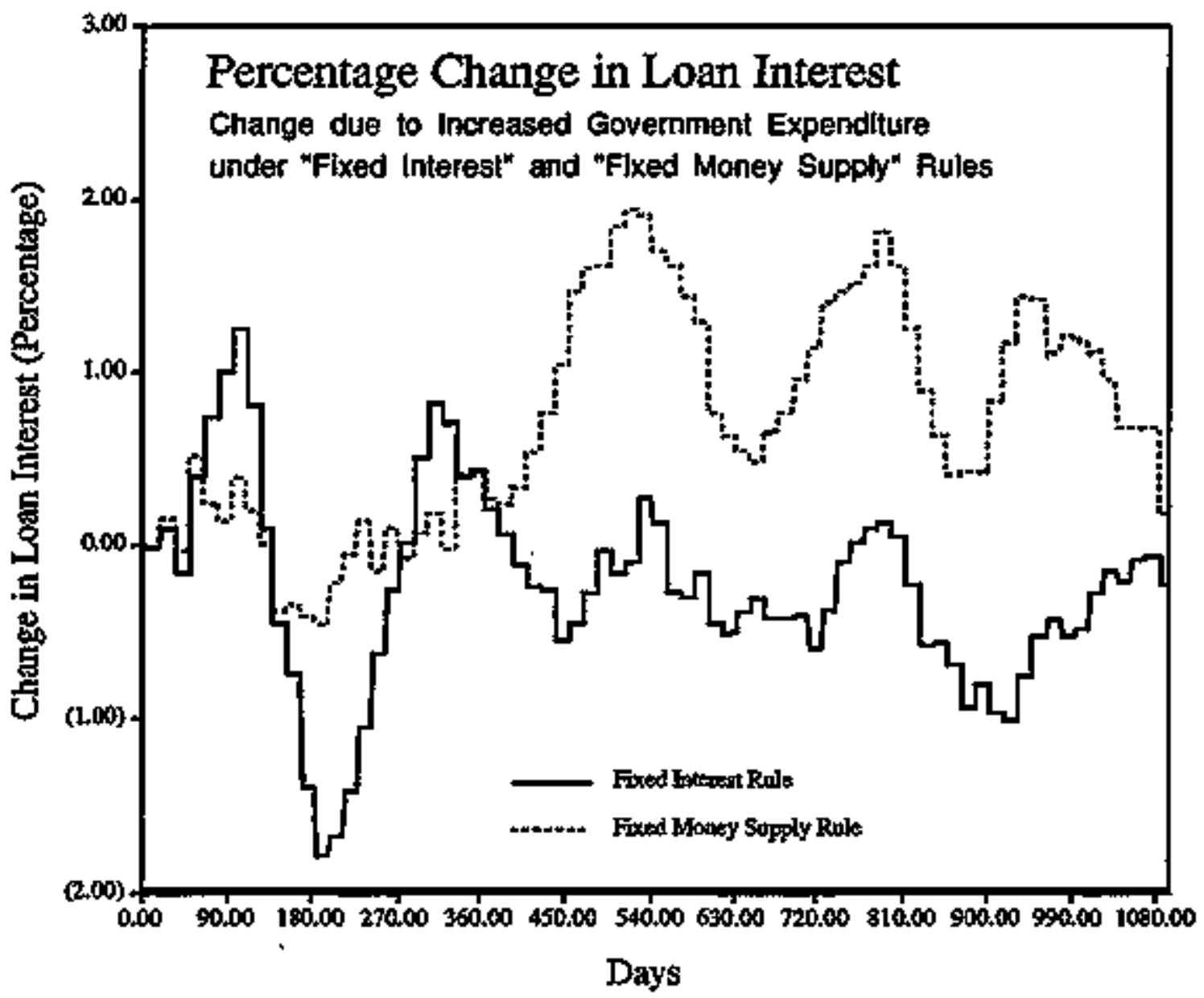

Graph B12 


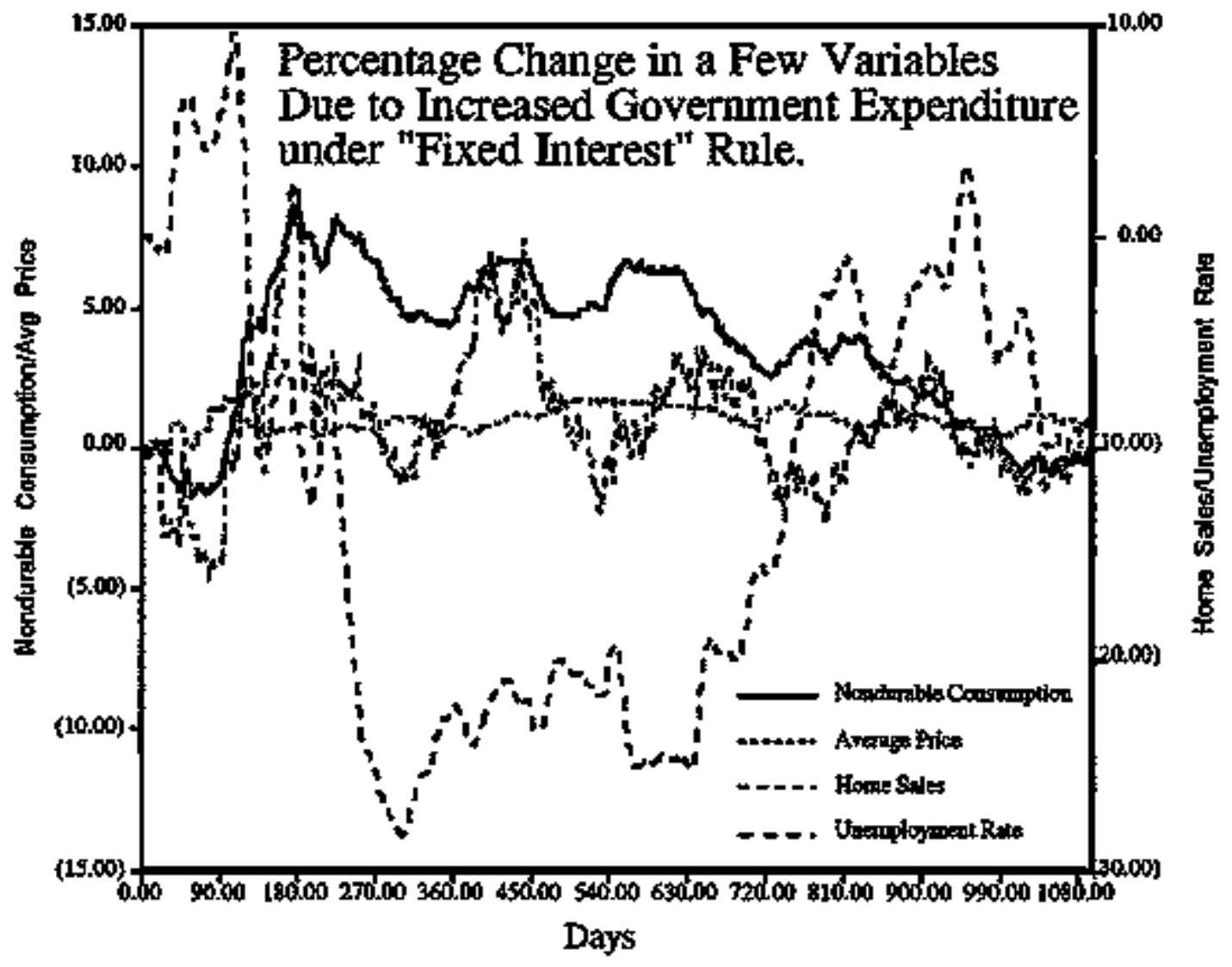

Graph B13 


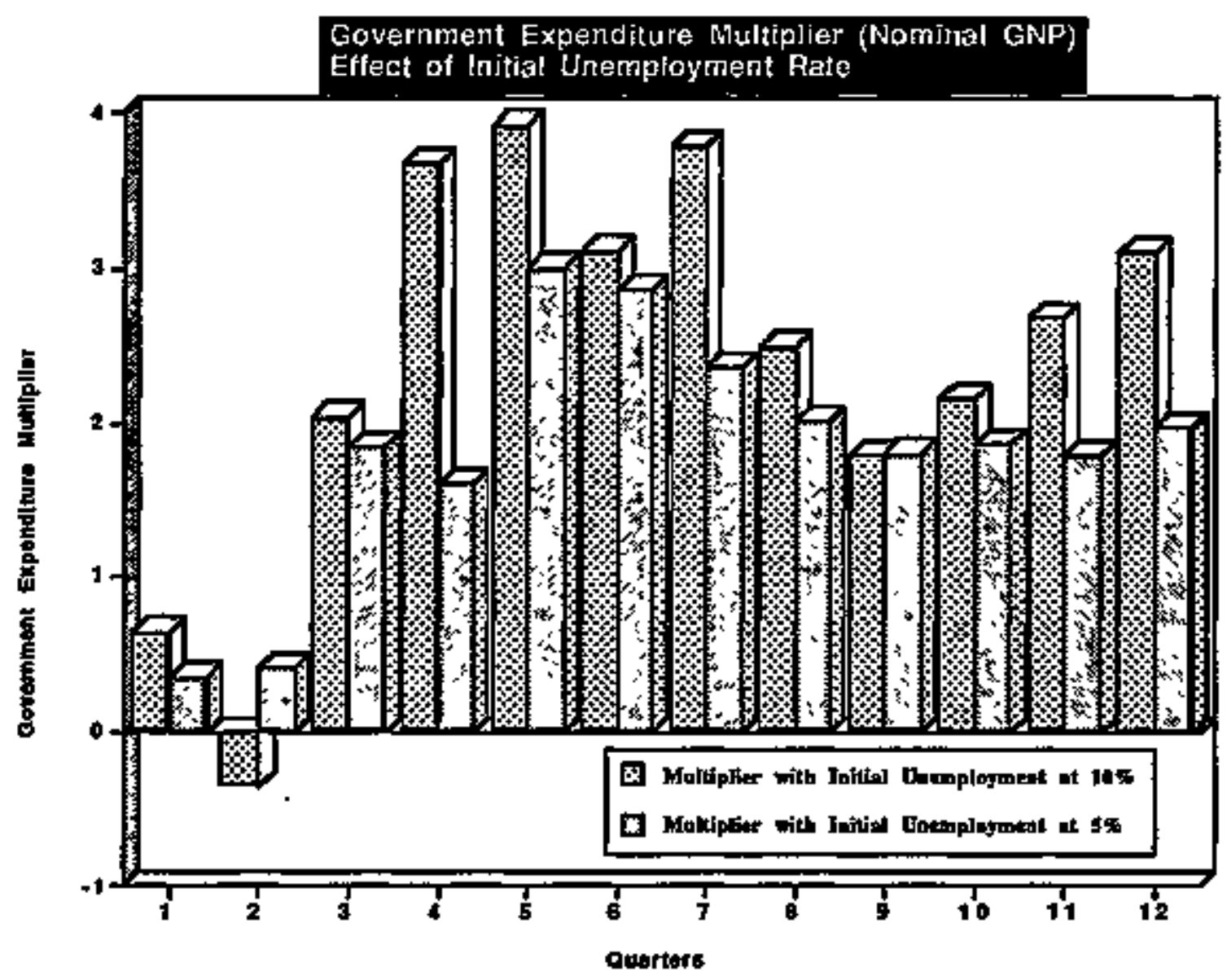

Graph B14

B-15 
Intentionally Left Blank 


\section{APPENDIX C}

\section{Run Time Results}




\section{Run Time Results}

\begin{tabular}{|c|c|c|c|c|c|c|}
\hline \# holds & \# nodes & $\begin{array}{c}1000 \text { steps } \\
\text { (sec) }\end{array}$ & $\begin{array}{l}2000 \text { steps } \\
\text { (sec) }\end{array}$ & $\begin{array}{c}3000 \text { steps } \\
\text { (sec) }\end{array}$ & $\begin{array}{c}4000 \text { steps } \\
\text { (sec) }\end{array}$ & $\begin{array}{c}5000 \text { steps } \\
(\mathrm{sec})\end{array}$ \\
\hline \multirow[t]{8}{*}{1000} & 4 & 617.58 & 1224.17 & 1835.22 & 2445.53 & 3054.85 \\
\hline & 4 & 628.30 & 124460 & 1865.79 & 2492.15 & 3116.16 \\
\hline & 5 & 549.29 & 1099.47 & 1672.59 & 2223.52 & 205.68 \\
\hline & 5 & 544.90 & 1008.17 & 1646.21 & 2188.56 & 2736.76 \\
\hline & 8 & 464,69 & 928.05 & 1404.40 & 1881.52 & 2361.05 \\
\hline & 8 & $467+14$ & 938.46 & 1427.55 & 1905.17 & 2440.88 \\
\hline & 10 & 430.59 & 876.96 & 1329,98 & 179000 & 228486 \\
\hline & 10 & 434,44 & 870.65 & 1317.52 & 1769.06 & 222738 \\
\hline \multirow[t]{2}{*}{$1003^{13}$} & 17 & 396.60 & 817.63 & 1264.07 & 1718.79 & 2154.82 \\
\hline & 17 & 397.47 & 820.41 & 1255.88 & 1695.75 & 2145.72 \\
\hline \multirow[t]{8}{*}{1000} & 20 & 405.16 & 829.70 & 1270.36 & 1717.29 & 2160.21 \\
\hline & 20 & 496.36 & 830.74 & 1268.75 & 1737.66 & 2189.30 \\
\hline & 25 & 415.30 & 851.72 & 1306.20 & 1771.53 & 2267.54 \\
\hline & 25 & 410.34 & $\$ 41.56$ & 1279.67 & 1724.48 & 2187.07 \\
\hline & 40 & 436.48 & 894.76 & 1365.22 & 1857.92 & 2353.98 \\
\hline & 40 & 437.14 & 904.21 & 1378.06 & 1866.60 & 2372.07 \\
\hline & 50 & 503.25 & 102854 & 1556.59 & 2092.47 & 2637,08 \\
\hline & 50 & 509.02 & 1040.00 & 1570.85 & 2120.60 & 2681.59 \\
\hline \multirow[t]{3}{*}{2000} & 4 & 1310.80 & 2556.26 & 3800.58 & 5042,98 & 6283.53 \\
\hline & 5 & 1155.51 & 2254,00 & 3356.05 & 4458.52 & 5557.45 \\
\hline & 10 & 921.03 & 1827.54 & 2734.80 & 3639.36 & $4546 \$ 9$ \\
\hline $1998^{15}$ & 18 & 810.01 & 1676.41 & 2590.07 & 3531.00 & 4468.47 \\
\hline \multirow[t]{3}{*}{2000} & 20 & 795.58 & 1652.60 & 2516.40 & 3399.79 & 4286.25 \\
\hline & 25 & 804.24 & 1648.74 & 2514.72 & 3405.83 & 4314.55 \\
\hline & 40 & 928,27 & I879.80 & 2851.90 & 3854.64 & 4874,27 \\
\hline \multirow[t]{5}{*}{5000} & 4 & 3859.60 & 7135.29 & 10443.86 & 1376679 & 17081.23 \\
\hline & 5 & 3314,26 & 6274.81 & 9253.54 & 12252.49 & 15238.51 \\
\hline & 10 & 2425.84 & 4761.53 & 713150 & 9529.57 & 11938.30 \\
\hline & 20 & 227490 & 4588.88 & 6989.25 & 9421.44 & 11884.27 \\
\hline & 25 & 2312.24 & 4684.58 & 7118.41 & 9611.16 & 12118.62 \\
\hline
\end{tabular}

${ }^{15}$ To nis Aspen, the uimber of households must be an exact multiple of the number of nodes. We do not belleve the addition ot subtraction of 2 or 3 agents qualitatrely affects our conclusions. 
DISTRIBUTION:

1 Dr. Guy H. Orcutt

P.O. Box 989

Grantham, NH 03753

1 Jim Shaw

BergenShaw International

1885 Cabana Dr.

San Jose, CA 95125-5608

5 Axei Leijonhurvud

Center for Computable Economics

Department of Economics

UCLA.

Los Angeles, CA 90095-1477

1 Jim Bullard

Federal Reserve Bank of St. Lowis 411 Locust St.

St. Louis, MO 63102

1 Steve L. Gibson

The Bionomics Institute

2173 East Francisco Blvd., Suite C

San Rafael, CA 94901

1 Richard G. Anderson

Federal Reserve Bank of St. Louis

411 Locust St.

St. Louis, MO 63102

1 Peter Yoo

Federal Reserve Bank of St. Louis 411 Locust St.

St. Louis, MO 63102

1 Dr. Barbara R. Bergmann

Economics Department

American University

Washington, DC 20016
1 Dan Sullivan

Federal Reserve Bank of Chicago

Division of Research

230 South LaSalle St.

Chicago, IL 60604

1 Jim Moser

Federal Reserve Bank of Chicago

Division of Research.

230 South LaSalle St.

Chicago, II 60604

I Dr. Lawtence R. Klein

University of Pennsylvania

Department of Economics

Philadelphia, PA 19104

I William Gorham

The Urban Institute

$2100 \mathrm{M}$ Street NW

Washington, DC 20037

1 Craig Coelen

The Urban Institute

$2100 \mathrm{M}$ Street $\mathrm{NW}$

Washington, DC 20037

I Christian Petersen

The Wotld Bank

1818 H Street NW

Washington, DC 20433

1 Brian McDonald

Bureau of Business and Economic Research

University of New Mexico

1920 Lomas NE

Albuquerque, NM 87131-6021

1 Mike Mckee

Economics Department

University of New Mexico

Albuquerque, NM 87131 
DISTRIBUTION (Continued):

1 Peter Tínsley

Federal Reserve Board

Division of Research and Statistics

Washington, DC 20551

1 Achla Marathe

Los Alamos National Laboratory

Computing and Communications Division

CIC-3, Computer Research \& Applications, $\mathrm{B} 265$

Los Alamos, NM 87545

1 Prof. Michael Jerison

SUNY at Albany

Economics Department

1400 Washington Ave.

Albany, NY 12222

1 Prof. Kajal Lahiri

SUNY at Albany

Economics Department

1400 Washington Ave.

Albany, NY 12222

1 Prof Hamilton Lankford

SUNY at Albany

Economics Department

1400 Washington Ave.

Albany, NY 12222

1 Dr. Jacques Jiha

Chief Economist, City of New York

Office of the Comptroller

Municipal Building

New York, NY 10007

1 Bob Mathews

Legislative Tex Study Commission

Agency Building 4, 14th Floor

Empire State Plaza

Albany, NY 12208
1 Stephanie Forrest

Computer Science Department

University of New Mexico

Albuquerque, NM 87131

1 Prof. John F. Kain

Economics Department

Harvard University

Cambridge, MA 02138

1 Prof. Ken Beauchemin

Economics Department

University of Colorado

Boulder, $\operatorname{CO} 80309$

1 Prof. Jeff Zax

Economics Department

University of Colorado

Boulder, CO 80309

I Dr. Frederick Dunbar

National Economic Research Associates

50 Main Street

White Plains, NY 10606

1 Prof. Kenneth Arrow

Economics Department

Encina Hall, 4th Floor

Stanford University

Stanford, CA 94305

1 Kurt E. Karl

The WEFA Group

401 City Avenue

Suite 300

Bala Cynwyd, PA 19004 
DISTRIBUTION (Continued):

1 Dr. Michael R. Donihue Associate Professor of Economics Department of Economics Colby College

Waterville, ME 04901

1 Brian Arthur Santa Fe Institurte 1399 Hyde Park Road

Santa Fe, NM $87501-8943$

1 Herbert E. Striner 4977 Battery Iane Bethesda, MD 20814

1 Mike Simmons Santa Fe Institute 1399 Hyde Park Road Santa Fe, NM 87501-8943

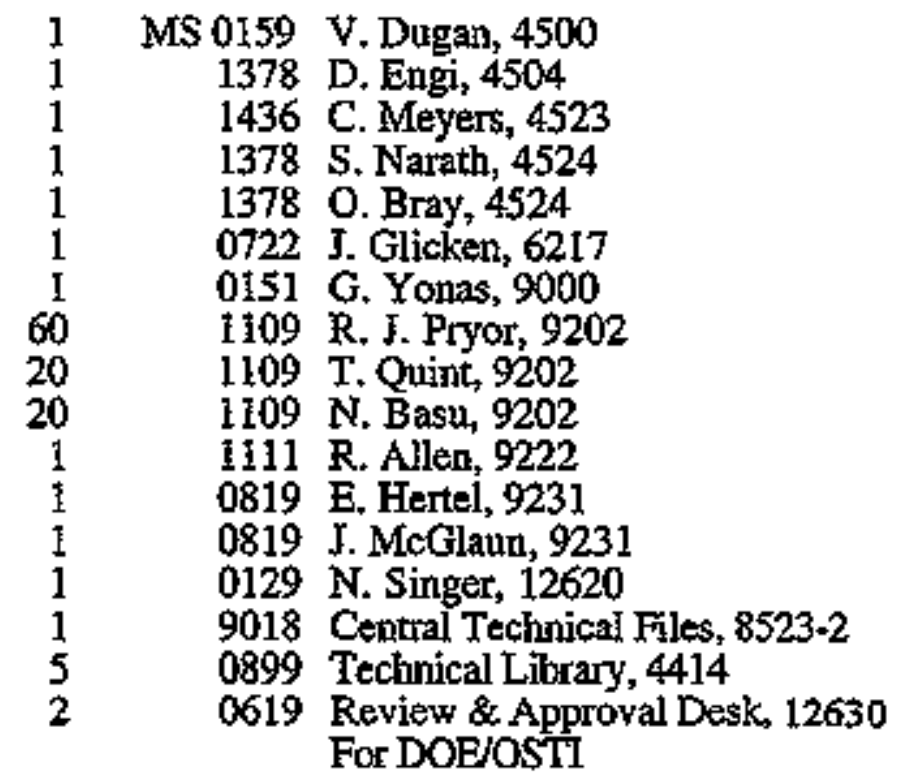

Prof. Martin Shubik Cowles Foundation Yale University 30 Hillhouse Ave. New Haven, CT 06520

1 E. H. Barsis I538 Catron Ave. SE Albuquerque, NM 87123

Daniel Bachman

Wefa, Inc.

800 Baldwin Tower

Eddystone, PA 19022

Dr. Alice M. Rivlin

Federal Reserve Board

Washington, DC 20551 